\title{
Floodplain restoration enhances denitrification and reach-scale nitrogen removal in an agricultural stream
}

\author{
Sarah S. Roley,${ }^{1,3}$ Jennifer L. Tank, ${ }^{1}$ Mia L. Stephen, ${ }^{1}$ Laura T. Johnson,${ }^{1,4}$ Jake J. Beaulieu, ${ }^{1,5}$ and \\ JONATHAN D. WitTER ${ }^{2}$ \\ ${ }^{1}$ Department of Biological Sciences, University of Notre Dame, Notre Dame, Indiana 46556 USA \\ ${ }^{2}$ Department of Food, Agricultural, and Biological Engineering, Ohio State University, Columbus, Ohio 43210 USA
}

\begin{abstract}
Streams of the agricultural Midwest, USA, export large quantities of nitrogen, which impairs downstream water quality, most notably in the Gulf of Mexico. The two-stage ditch is a novel restoration practice, in which floodplains are constructed alongside channelized ditches. During high flows, water flows across the floodplains, increasing benthic surface area and stream water residence time, as well as the potential for nitrogen removal via denitrification. To determine two-stage ditch nitrogen removal efficacy, we measured denitrification rates in the channel and on the floodplains of a two-stage ditch in northcentral Indiana for one year before and two years after restoration. We found that instream rates were similar before and after the restoration, and they were influenced by surface water $\mathrm{NO}_{3}{ }^{-}$concentration and sediment organic matter content. Denitrification rates were lower on the constructed floodplains and were predicted by soil exchangeable $\mathrm{NO}_{3}{ }^{-}$concentration. Using storm flow simulations, we found that two-stage ditch restoration contributed significantly to $\mathrm{NO}_{3}^{-}$removal during storm events, but because of the high $\mathrm{NO}_{3}{ }^{-}$loads at our study site, $<10 \%$ of the $\mathrm{NO}_{3}^{-}$load was removed under all storm flow scenarios. The highest percentage of $\mathrm{NO}_{3}{ }^{-}$removal occurred at the lowest loads; therefore, the two-stage ditch's effectiveness at reducing downstream $\mathrm{N}$ loading will be maximized when the practice is coupled with efforts to reduce $\mathrm{N}$ inputs from adjacent fields.
\end{abstract}

Key words: agriculture; denitrification; floodplain; stream restoration; Tippecanoe River, north-central Indiana, USA; two-stage ditch.

\section{INTRODUCTION}

Anthropogenic activities have doubled the input of reactive nitrogen $(\mathrm{N})$ onto landscapes across the globe, which has increased $\mathrm{N}$ loading to freshwater and marine systems (Vitousek et al. 1997). In the agricultural Midwest, USA, extensive $\mathrm{N}$ fertilization and artificial drainage has resulted in high $\mathrm{N}$ loading rates to agricultural streams: $\sim 20$ million hectares of agricultural soils in the Mississippi River Basin are drained with subsurface tile drains, which discharge to incised streams or ditches (Osborne and Wiley 1988, Johnson et al. 1997, Galloway et al. 2003). Channelization and tile drainage ensure rapid conveyance of water from crop fields, which improves agricultural production, but reduces water contact time with soils and sediments, and ultimately reduces $\mathrm{N}$ retention on fields (Randall et al. 1997, Royer et al. 2006). The export of excess $\mathrm{N}$ from the agricultural Midwest has been linked to coastal

Manuscript received 1 March 2011; revised 21 July 2011; accepted 1 August 2011. Corresponding Editor: C. Nilsson.

3 E-mail: sroley@nd.edu

${ }^{4}$ Present address: School of Public and Environmental Affairs, Indiana University, Bloomington, Indiana 47405 USA.

5 Present address: U.S. EPA, Office of Research and Development, Cincinnati, Ohio 45268 USA. hypoxia in the Gulf of Mexico (Rabalais et al. 2002), as well as locally contaminated drinking water (Fan and Steinberg 1996) and loss of freshwater biodiversity (Carpenter et al. 1998). Best management practices (BMPs), which improve biological $\mathrm{N}$ removal in agricultural streams, while simultaneously meeting the drainage needs of the agricultural community, may improve downstream water quality without loss of agricultural function.

Agricultural areas in the Midwest typically have low relief and poor drainage. As a result, artificial subsurface drainage (i.e., tile drains) is necessary for crop growth to occur. In addition, many streams are managed by county-level drainage commissions who use dredging to create trapezoid-shaped stream channels. These channels are effective at quickly moving water downstream, but often are subject to bank slumping and may require dredging to maintain their shape. An alternative management strategy to the trapezoidal channel is the two-stage ditch, in which floodplains are restored alongside the stream channel (Fig. 1D and E; Powell et al. 2007). In this design, tile drains flow directly onto the floodplains. During high flows, water spreads onto the floodplains and slows down, depositing fine sediments. The floodplains also decrease shear stress, which results in greater channel stability and decreased erosion (Powell et al. 2007). The two-stage ditch design mimics 

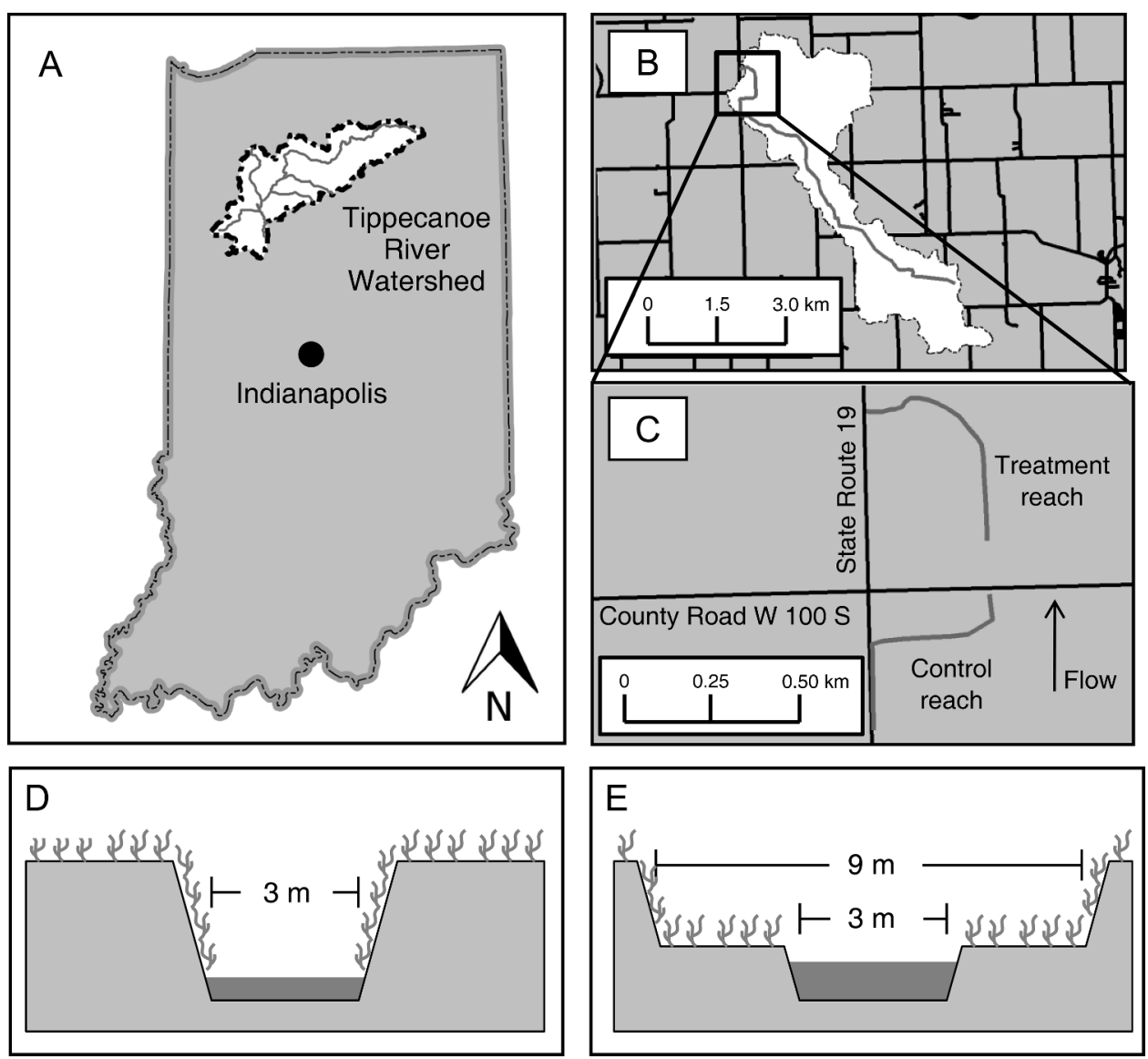

FIG. 1. (A) Location of the Tippecanoe River watershed within Indiana, USA. (B) Shatto Ditch watershed, with the study area denoted by the black box. (C) The control and treatment reach of Shatto Ditch. Note that the control reach is upstream of the treatment reach. (D) Cross section of a trapezoidal stream channel. (E) Cross section of the two-stage ditch restoration, which was completed on the treatment reach. The base flow channel is left intact, and floodplains are excavated on both sides of the base flow channel.

natural fluvial processes; an unmaintained, channelized stream typically forms small floodplains ("naturalized" floodplains) as a result of bank slumping, undercutting, and sediment deposition (Landwehr and Rhoads 2003). The floodplains of these tile-drained, agriculturally influenced channels are typically inundated numerous times each year during storm flows (Landwehr and Rhoads 2003, Kallio 2010b). In addition to improving channel stability, the two-stage ditch may enhance $\mathrm{N}$ removal by increasing water residence time and providing additional bioreactive surface area for transformations of nitrogen, including denitrification. Through heterotrophic microbial denitrification, nitrate $\left(\mathrm{NO}_{3}{ }^{-}\right)$is converted to nitrogenous gases in the presence of organic carbon and anoxic conditions in the sediments (Knowles 1982). Thus, denitrification results in a permanent removal of $\mathrm{N}$ from the system (Galloway et al. 2003).

Floodplain soils may be better suited for microbial denitrification than upland fields or riparian grass buffer strips, particularly in the tile-drained landscape of the agricultural Midwest. Floodplain soils are closer to the water table and hydrologically connected to surface water, resulting in higher soil moisture and redox conditions suitable for denitrification (Kaushal et al. 2008, Gift et al. 2010). In tile-drained landscapes, high$\mathrm{NO}_{3}^{-}$groundwater is shunted through underground drainage pipes, which minimizes its interaction with soils and limits the denitrification potential of buffer strips (Fennessy and Cronk 1997, Ducros and Joyce 2003). Furthermore, plant matter is often removed from buffer strips and crop lands each year during harvest, which decreases organic carbon availability and may further limit the denitrification potential of buffer strips (Hedin et al. 1998).

Natural floodplains have been found to be generally effective at $\mathrm{N}$ removal, but have mainly been studied in mid-order rivers (Pinay et al. 1993, Hoffmann et al. 1998, Van Der Lee et al. 2004, Schilling and Jacobson 2009). Additionally, floodplain restorations have been largely examined in the context of hydrologic reconnection with existing floodplains, where success has been 
mixed. In one case, denitrification rates remained unchanged post-restoration (Orr et al. 2007). In other studies, hydrologic reconnection with floodplains increased $\mathrm{N}$ removal rates by creating favorable redox conditions, increasing delivery of $\mathrm{NO}_{3}{ }^{-}$to soils with high denitrification potential, and increasing floodplain water residence time (Groffman and Crawford 2003, Sheibley et al. 2006, Kaushal et al. 2008).

In contrast to previous floodplain restoration studies, the two-stage ditch results in the creation of a novel floodplain habitat. As a result, it is unclear how this new habitat will function. Organic carbon is potentially limiting, because soil removal during floodplain excavation may reveal inorganic, formerly subsurface substrates. Microbial populations could also be potentially limiting; we do not know if denitrifiers will be present in freshly excavated soil, or how long it will take for them to colonize. Finally, although two-stage restoration is not a direct manipulation of the stream channel, over time it can result in channel narrowing (Powell et al. 2007), which could increase water velocity for flows below the floodplain elevation, and potentially change stream sediment characteristics and resultant instream $\mathrm{N}$ removal processes.

The two factors that will determine two-stage ditch efficacy for reach-scale $\mathrm{N}$ removal are areal denitrification rates and water residence time. In general, $\mathrm{N}$ removal rates increase with residence time, because there is more time for surface water to interact with sediment denitrifiers before the water is exported downstream (Seitzinger et al. 2006). Floodplain restoration increases water residence time during floodplain inundation, because the water spreads out over a greater area and thus velocities decline. In addition, high-nitrate stream water is exposed to soil denitrifiers in restored floodplains. We predict that these interacting factors will increase reach-scale $\mathrm{N}$ removal in the two-stage ditch.

Two-stage restoration is a novel BMP that allows drainage while maintaining channel stability. It has the potential to improve biological $\mathrm{N}$ removal rates, as well, but its efficacy in that regard has not been evaluated. The objective of this research was to determine if floodplain restoration via the two-stage ditch promotes microbial denitrification at the stream reach scale. Results from this study identify controls on both instream and floodplain denitrification rates, estimate the efficiency of $\mathrm{NO}_{3}{ }^{-}$removal relative to stream water $\mathrm{NO}_{3}{ }^{-}$loads, and evaluate the potential role of the twostage ditch in the management of $\mathrm{N}$ loading in agricultural landscapes.

\section{Materials and Methods}

\section{Site description}

We conducted our study in Shatto Ditch, which is a tributary of the Tippecanoe River in north-central Indiana, USA (Fig. 1). Shatto is a first-order stream, and base flow discharge ranges from 12 to $174 \mathrm{~L} / \mathrm{s}$. The surrounding landscape is primarily tile-drained row crop agriculture in a maize-soy bean rotation. The stream is surrounded by a $3 \mathrm{~m}$ wide grass buffer strip that is periodically mowed or burned. Shatto Ditch has historically been maintained as a drainage ditch with steep slopes and an incised, trapezoid-shaped channel. As a result, it has a flashy hydrograph and high concentrations of dissolved inorganic nutrients. The stream bed is primarily a mix of fine benthic organic matter (FBOM) and sand, although gravel is present after spring snowmelt, particularly in the upstream portion of the reach.

\section{Experimental design}

We employed a before-after-control-impact (BACI) design for our study (Stewart-Oaten et al. 1986) by establishing a 600-m downstream treatment reach, paired with a 600-m upstream control reach, with a $50-\mathrm{m}$ buffer located between the reaches. We measured denitrification rates on sediments collected every two months in both reaches for 13 months prior to the twostage restoration (September 2006-October 2007). After the restoration, we collected instream and floodplain denitrification data for two years (December 2008November 2009). A summary of the field measurements is presented in Table 1.

Floodplains in the treatment reach of Shatto Ditch were restored in November 2007. To determine floodplain height relative to the stream bottom, we measured the height of naturally formed floodplains, where they existed. Using a backhoe, the side slopes were excavated on each side of the stream to the desired depth (mean = $0.4 \mathrm{~m}$ from stream bottom in the center of the channel to the floodplain; Kallio 2010a), creating a new $3 \mathrm{~m}$ wide floodplain (Fig. 1D and E). The stream channel had an average width of $2.7 \mathrm{~m}$; thus, the two-stage ditch restoration more than tripled the stream corridor area.

\section{Field sampling of stream sediments and floodplain soils}

Every two months, we collected sand and FBOM from the stream channel, to a depth of $2 \mathrm{~cm}$, at evenly spaced transects (25 $\mathrm{m}$ apart), using a $3.6 \mathrm{~cm}$ diameter polyvinyl chloride (PVC) corer. We collected sufficient sediments for five replicate denitrification assays for each substrate type from each reach, including nutrient limitation assays (see the next section, Laboratory denitrification assays on sediments and soils). In April and June of 2009, the control reach contained primarily sand and gravel (66\% sand, 16\% gravel in April; and $58 \%$ sand, $23 \%$ gravel in June), so we sampled gravel instead of FBOM. During each sampling, we also characterized the sediment every $10 \mathrm{~cm}$ along each transect, and used these habitat data to determine the proportion of the channel containing each substrate type, as well as average channel width and stream channel area (average width multiplied by channel length).

After the two-stage restoration, we also collected floodplain soil cores for denitrification assays. At five 
TABle 1. Summary of measurements made in this study at Shatto Ditch watershed, Indiana, USA.

\begin{tabular}{|c|c|c|c|c|c|c|}
\hline Sample location & $\begin{array}{l}\text { Sediment } \\
\text { depth }(\mathrm{cm})\end{array}$ & $\begin{array}{c}\text { Explanatory } \\
\text { variables }\end{array}$ & $\begin{array}{l}\text { Sampling } \\
\text { frequency }\end{array}$ & Substrate type & Slurry conditions & $\begin{array}{l}\text { Experimental } \\
\text { reach } \dagger\end{array}$ \\
\hline Stream channel & $0-2$ & $\begin{array}{l}\text { stream water } \\
\mathrm{NO}_{3}{ }^{-} \\
\text {sediment } \\
\text { organic matter }\end{array}$ & $\begin{array}{l}\text { pre- and post- } \\
\text { restoration, } \\
\text { every } 2 \\
\text { months } \\
(n=19)\end{array}$ & $\begin{array}{l}\text { fine benthic } \\
\text { organic matter } \\
(\text { FBOM), sand }\end{array}$ & $\begin{array}{l}\text { stream water } \\
\text { added }\end{array}$ & CTL, TRT \\
\hline Floodplains & $\begin{array}{c}0-15 \text {, in } 5 \mathrm{~cm} \\
\text { increments }\end{array}$ & $\begin{array}{l}\text { soil-exchangeable } \\
\mathrm{NO}_{3}^{-}, \text {soil } \\
\text { organic } \\
\text { matter, soil } \\
\text { gravimetric } \\
\text { water content }\end{array}$ & $\begin{array}{l}\text { post-restoration, } \\
\text { every } 2 \\
\text { months } \\
(n=10)\end{array}$ & floodplain soils & $\begin{array}{l}\text { ambient } \\
\text { conditions } \\
\text { or stream } \\
\text { water added }\end{array}$ & TRT \\
\hline
\end{tabular}

$\dagger$ Abbreviations are: CTL, control reach; TRT, treatment reach.

randomly chosen sites, we collected two adjacent soil cores, each $15 \mathrm{~cm}$ long, with a PVC corer. These cores almost always penetrated the water table. We extruded the cores onto a plastic tray, and cut them into $5-\mathrm{cm}$ sections.

\section{Laboratory denitrification assays on sediments and soils}

Within $24 \mathrm{~h}$ of stream sediment or floodplain soil collection, we estimated microbial denitrification rates using the redox-optimized chloramphenicol-amended acetylene block technique (Smith and Tiedje 1979, Royer et al. 2004, Arango et al. 2007). Acetylene $\left(\mathrm{C}_{2} \mathrm{H}_{2}\right)$ blocks the microbial conversion of $\mathrm{N}_{2} \mathrm{O}$ to $\mathrm{N}_{2}$, allowing $\mathrm{N}_{2} \mathrm{O}$, which is more easily measured, to accumulate in assay bottles. Chloramphenicol is an antibiotic that blocks the production of de novo denitrifying enzymes (Brock 1961), and reduces the bottle effects of laboratory denitrification assays by limiting their response to ideal redox conditions (Smith and Tiedje 1979). When chloramphenicol is added, denitrification rates measured with the acetylene block technique are comparable to other methods, particularly under short-term incubations (Bernot et al. 2003). We did not artificially elevate nutrient concentrations in the assay bottles, but instead used only ambient stream water for incubations. We feel this methodological approach is suitable for the unconsolidated sediments and high- $\mathrm{NO}_{3}{ }^{-}$water (range: $2.4-9.8 \mathrm{mg} \mathrm{NO}_{3}{ }^{-} \mathrm{N} / \mathrm{L}$ ) in our study stream (Royer et al. 2004, Inwood et al. 2005, Arango et al. 2007). These redox-optimized, ambient nutrient incubations are easily replicated over space and time and do not require the addition of large quantities of isotopically enriched ${ }^{15} \mathrm{NO}_{3}{ }^{-}$.

For each sediment replicate, we homogenized the sample and subsampled $5 \mathrm{~mL}$ for analysis of dry mass (DM) and ash free dry mass (AFDM). We placed $25 \mathrm{~mL}$ of sediment in a $125-\mathrm{mL}$ glass bottle with a rubber septum cap, and added $45 \mathrm{~mL}$ of stream water, along with $5 \mathrm{~mL}$ of $3.1 \mathrm{mmol} / \mathrm{L}$ chloramphenicol, to achieve a final slurry concentration of $0.21 \mathrm{mmol} / \mathrm{L}$ chloramphenicol (Bruesewitz et al. 2008). We cut each soil core in half, and used one half each for denitrification measurements and nutrient extraction. Because the soils were generally too moist for sieving, we used a metal spatula to cut the core into small pieces before placing in the assay bottles, which allowed $\mathrm{C}_{2} \mathrm{H}_{2}$ to more easily diffuse into the soils (Groffman et al. 1999). For each pair of adjacent cores, we incubated one without stream water during the denitrification assay, and one with stream water added to simulate floodplain conditions during storm flows. Although stream water $\mathrm{NO}_{3}{ }^{-}$and organic carbon concentrations may differ between storm flows and the base flow conditions under which we collected the assay water (e.g., Royer et al. 2004, Vidon et al. 2008), the stream water amendments nonetheless provide an indication of whether floodplain denitrification responded to inundation, although the magnitude of the response may only be an approximation. If the floodplains happened to be naturally inundated on the sampling date (which occurred in February 2008), we added stream water to all samples, and collected cores at 10 randomly chosen sites, instead of pairs at five sites. We added chloramphenicol to all bottles, as above.

We sealed all bottles with septum caps and sparged with ultra-high purity $\mathrm{N}_{2}$ for 5 min, shaking periodically to remove oxygen. After sparging, we vented the bottles to return them to ambient atmospheric pressure, and then added $15 \mathrm{~mL}$ of pure $\mathrm{C}_{2} \mathrm{H}_{2}$, for a $10 \%$ headspace concentration of $\mathrm{C}_{2} \mathrm{H}_{2}$. We generated $\mathrm{C}_{2} \mathrm{H}_{2}$ by mixing calcium carbide with deionized water (Arango and Tank 2008).

We incubated each assay bottle for $4 \mathrm{~h}$ and took five headspace samples over that time period, each approximately $1 \mathrm{~h}$ apart at $0.25,1.25,2.25,3.25$, and $4.25 \mathrm{~h}$. We shook each bottle for several seconds prior to sampling to equilibrate the gases in the headspace and the slurry, then removed $5 \mathrm{~mL}$ of gas with a syringe and injected the gas into pre-evacuated 3-mL serum vials with rubber septa (Wheaton, Millville, New Jersey, USA). We maintained constant pressure in the assay bottles by injecting $5 \mathrm{~mL}$ of $10 \% \mathrm{C}_{2} \mathrm{H}_{2}$ (balance of $\mathrm{N}_{2}$ ) after sampling. We incubated all bottles at room temperature to minimize variability among substrates and reaches.

To determine if stream sediment denitrification was limited by the availability of $\mathrm{NO}_{3}{ }^{-}$or dissolved organic carbon (DOC) in stream water, we completed nutrient limitation assays on most sampling dates. In these 
assays, we added $\mathrm{NO}_{3}{ }^{-}$(to $1.1 \mathrm{mg} / \mathrm{L}$ above background) and glucose (to $2.7 \mathrm{mg} / \mathrm{L}$ above background) singly and in combination, creating three additional treatments: $+\mathrm{NO}_{3}{ }^{-},+\mathrm{DOC}$, and $+\mathrm{NO}_{3}{ }^{-}+$DOC. We prepared these samples as described in the previous three paragraphs, but used a nutrient-amended chloramphenicol solution $\left(\mathrm{NO}_{3}{ }^{-}\right.$as $\mathrm{KNO}_{3}^{-}\left[10 \mathrm{mg} \mathrm{NO}{ }^{-}-\mathrm{N} / \mathrm{L}\right]$, and $\mathrm{DOC}$ as glucose [24 mg C/L]) (Royer et al. 2004, Bruesewitz et al. 2009). We had three replicates of each nutrient treatment for each substrate and stream reach. We completed these assays only on stream sediments, not on floodplain soils, due to time and equipment limitations.

To determine carbon quality, we also measured the carbon dioxide $\left(\mathrm{CO}_{2}\right)$ concentration in the gas samples (see next paragraph) and calculated the ratio of $\mathrm{CO}_{2}$ production to $\mathrm{N}_{2} \mathrm{O}$ production (in $\mu \mathrm{mol} / \mathrm{h}$ ) on a subset of sampling dates. A higher ratio corresponds to lower carbon quality; it requires more carbon to be oxidized per mole of $\mathrm{NO}_{3}{ }^{-}$reduced (Pfenning and McMahon 1996). In using this index, we assume that other anaerobic heterotrophic processes (e.g., sulfate reduction) are equal among streams, substrates, and sampling dates. In addition, we only used this index when $\mathrm{NO}_{3}{ }^{-}$ was not limiting (i.e., on floodplain samples that were incubated with surface water, and instream samples that were not $\mathrm{NO}_{3}^{-}$limited, as determined by the nutrient limitation assays).

All gas analysis was completed on a Varian CP-3800 gas chromatograph (Varian, Walnut Creek, California, USA), equipped with an electron capture detector (ECD), a thermal conductivity detector (TCD), a Haye SepQ column (AllTech, Deerfield, Illinois, USA), a valve to vent water and $\mathrm{C}_{2} \mathrm{H}_{2}$ away from the detector, and a CombiPAL autosampler (CTC Analytics, Zwingen, Switzerland). The injector temperature was set at $50^{\circ} \mathrm{C}$, the column oven at $50^{\circ} \mathrm{C}$, the $\mathrm{ECD}$ at $300^{\circ} \mathrm{C}$, and the TCD at $120^{\circ} \mathrm{C}$. We used the ECD to measure $\mathrm{N}_{2} \mathrm{O}$ concentration and the TCD to measure $\mathrm{CO}_{2}$ concentration. The carrier gases were ultra-high purity $\mathrm{N}_{2}$ and ultra-high purity helium, respectively. We applied Bunsen coefficients to account for gas dissolved in the slurry (Inwood et al. 2005), then plotted $\mathrm{N}_{2} \mathrm{O}$ and $\mathrm{CO}_{2}$ mass vs. time and used the slope of the best-fit linear regression line to determine production rates. We scaled the $\mathrm{N}_{2} \mathrm{O}$ production rate (units: $\mu \mathrm{g} \mathrm{N}_{2} \mathrm{O}-\mathrm{N} / \mathrm{h}$ ) to the amount of dry mass (DM), ash free dry mass (AFDM), and stream area $\left(\mathrm{m}^{2}\right)$ in the assay bottle. We also calculated habitat-weighted denitrification rates by weighting areal denitrification rates by the proportion of the reach containing each substrate (units: $\mu \mathrm{g} \mathrm{N}_{2} \mathrm{O}-$ $\left.\mathrm{N} \cdot \mathrm{m}^{-2} \cdot \mathrm{h}^{-1}\right)$. We used the habitat-weighted, areal denitrification rates (denoted $U_{\mathrm{dstr}}$ [denitification in stream]) in our calculations of reach-scale $\mathrm{NO}_{3}{ }^{-}$removal (see Reach-scale $\mathrm{NO}_{3}^{-}$removal calculations).

\section{Temperature experiment}

To determine the effect of incubating samples at room temperature, we did two temperature experiments. We collected sand and FBOM from the treatment reach in October 2007, when the stream temperature was $14^{\circ} \mathrm{C}$, and February 2008, when the stream temperature was $1^{\circ} \mathrm{C}$. On each sampling date, we measured denitrification rates as described in the previous section, but incubated five replicate samples each at $0^{\circ} \mathrm{C}, 6^{\circ} \mathrm{C}, 15^{\circ} \mathrm{C}$, and $22^{\circ} \mathrm{C}$. We plotted temperature vs. denitrification rate $\left(\mu \mathrm{g} \mathrm{N} \mathrm{N}_{2} \mathrm{O}\right.$ $\mathrm{N} / \mathrm{h}$ ) and fitted a simple linear regression (SLR) to the resulting data to determine the temperature correction. The distribution of stream temperatures from our regular denitrification sampling dates (taken every two months) was bi-modal (cold ranged from $0^{\circ} \mathrm{C}$ to $7^{\circ} \mathrm{C}$, and warm ranged from $10^{\circ} \mathrm{C}$ to $19^{\circ} \mathrm{C}$ ), and we applied the temperature correction from February to the cold dates and the October correction to the warm dates. To apply the correction, we multiplied the slope of the bestfit regression line by the difference between the stream temperature and the incubation temperature, and subtracted that value from the $\mathrm{N}_{2} \mathrm{O}$ production rate (units: $\mu \mathrm{g} \mathrm{N}_{2} \mathrm{O}-\mathrm{N} / \mathrm{h}$ ). We then scaled the $\mathrm{N}_{2} \mathrm{O}$ production rate by DM, AFDM, and area, as described in the previous section, and compared the temperature-corrected rates to the room temperature rates.

\section{Ancillary physicochemical variables}

We measured a suite of physicochemical variables, including surface water chemistry, floodplain soil chemistry, and stream discharge. We collected surface water samples on every sampling date by filtering $60 \mathrm{~mL}$ of stream water (glass fiber filters, 1- $\mu \mathrm{m}$ nominal pore size; Pall, Ann Arbor, Michigan, USA) into acidwashed, stream water-rinsed, high-density polyethylene bottles and freezing for subsequent analysis in the laboratory. We analyzed surface water and soil extractions (see next paragraph) for $\mathrm{NO}_{3}{ }^{-} \mathrm{N}$ on a Lachat QC8500 Flow Injection Autoanalyzer (Lachat Instruments, Loveland, Colorado, USA) using the cadmium reduction method (APHA 1995).

We extracted soil nutrients from all floodplain samples within $3 \mathrm{~d}$ of field collection. Before the extractions, soil samples were kept in closed sample containers at $4^{\circ} \mathrm{C}$. In these extractions, we added $40 \mathrm{~mL}$ of $2 \mathrm{~mol} / \mathrm{L}$ potassium chloride $(\mathrm{KCl})$ to $4 \mathrm{~g}$ of soil at field moisture, agitated the samples at $100 \mathrm{rpm}$ on a shaker table for $1 \mathrm{~h}$, filtered, and then froze the supernatant for later analysis (SSSA 1996). Extractable nutrient concentrations were expressed per unit dry mass.

To estimate continuous stream discharge, we deployed capacitance meters (Odyssey, Christchurch, New Zealand), which recorded stream stage every $20 \mathrm{~min}$. We then created a stage-discharge relationship by measuring stream discharge directly at a range of flow conditions (Gore 2006). On several dates, we released a 20-L slug of saturated sodium chloride or rhodamine dye solution at the upstream end of both the control and treatment reaches (Gordon et al. 1992). We placed a Hydrolab Minisonde (Hach, Loveland, Colorado, USA) at the 
downstream end of the reach and recorded conductivity or fluorescence. We calculated discharge as

$$
Q=V C / \int\left(C_{t}-C_{\mathrm{b}}\right) \mathrm{d} t
$$

where $Q$ is discharge $(\mathrm{L} / \mathrm{s}), V$ is volume of dye or salt solution released, $C$ is the concentration of dye or conductivity of $\mathrm{NaCl}$ release solution, $C_{t}$ is the stream water fluorescence or conductivity at the downstream monitoring station at time $t$, and $C_{\mathrm{b}}$ is the background fluorescence or conductivity in the stream. We calculated average velocity as the time from release to peak fluorescence or conductivity. On the date of each slug release, we also measured the wetted width at 23 evenly spaced transects along the length of the reach. We then calculated average depth over the reach as

$$
z=Q /(v w)
$$

where $z$ is average depth, $v$ is mean velocity, and $w$ is mean width. To estimate continuous average depth, we developed a relationship between measured average depth and capacitance meter stage. To account for time periods when the capacitance meters failed, we also created a relationship between discharge measured with slug releases and the nearby Eel River USGS gauge (available online). ${ }^{6}$

In addition, we used the stage data to determine the frequency of bank-full events. Bank-full events occur when water flows out of the main channel and onto the floodplains, whereas ditch-full events occur when water flows out of the ditch and onto the field.

\section{Reach-scale $\mathrm{NO}_{3}{ }^{-}$removal calculations}

We calculated reach-scale $\mathrm{N}$ removal with an application of stream nutrient spiraling metrics (Newbold et al. 1981), using calculations from Royer et al. (2004). First, we calculated the uptake velocity of $\mathrm{NO}_{3}{ }^{-}$as a result of denitrification $\left(V_{\mathrm{f}, \mathrm{dn}}\right)$ by dividing $\mathrm{NO}_{3}{ }^{-}$uptake via denitrification $\left(U_{\text {dstr }}\right)$ by stream water $\mathrm{NO}_{3}{ }^{-}$ concentration $\left(\mathrm{C}, \mathrm{mg} \mathrm{NO}_{3}{ }^{-}-\mathrm{N} / \mathrm{m}^{3}\right)$. We used the habitat-weighted denitrification rate for $U$, as described previously in the section Laboratory denitrification assays on sediments and soils. Next, we calculated the metric $-k$ (percentage per day), which is the $\mathrm{NO}_{3}{ }^{-}$loss rate attributed to denitrification (Alexander et al. 2000), according to

$$
-k=\left(V_{\mathrm{f}, \mathrm{dn}}\right) / z .
$$

In addition, we calculated denitrification uptake length $\left(S_{\mathrm{w}, \mathrm{dn}}\right)$, which is the average distance traveled by a molecule of $\mathrm{NO}_{3}{ }^{-}$before being denitrified:

$$
S_{\mathrm{w}, \mathrm{dn}}=(v z) / V_{\mathrm{f}, \mathrm{dn}} .
$$

The floodplains were inundated on only one sampling date (February 2008). For all other dates, the floodplains were not inundated, and were therefore unlikely

${ }^{6}$ http://waterdata.usgs.gov/nwis/uv?03328000 to influence $-k$ or $S_{\mathrm{w}, \mathrm{dn}}$. To estimate the influence of the constructed floodplains when they were inundated, we simulated nutrient spiraling metrics for a trapezoidal and a two-stage ditch under a range of flow conditions. In both simulations, we varied $Q$ from $174 \mathrm{~L} / \mathrm{s}$ (the lowest $Q$ under water starts to flow onto the floodplains) to $1600 \mathrm{~L} / \mathrm{s}$ (ditch-full flow) while holding $U$ and $C$ constant. Stream width was set equal to the width of the trapezoidal channel and two-stage channels (i.e., active stream channel plus floodplains), $3 \mathrm{~m}$ and $9 \mathrm{~m}$ width, respectively. Mean depth was calculated from our empirical relationship between discharge and depth (see the previous section). Water velocity was calculated as

$$
v=Q /(w z)
$$

$\mathrm{NO}_{3}{ }^{-}$removal rate was set equal to the median habitatweighted areal denitrification rate supported by the stream sediments $\left(U_{\mathrm{dstr}}\right)$ in 2008 and 2009. In the twostage ditch simulation, $U_{\mathrm{dn}}$ was calculated as the median habitat-weighted areal denitrification rate supported by the stream sediments and floodplain soils ( $U_{\text {ddit }}$; [denitrification in ditch]) in 2008 and 2009. We calculated $-k$ and $S_{\mathrm{w}}$ for both simulations as described in the previous paragraph.

In addition to the reach-scale $\mathrm{NO}_{3}{ }^{-}$removal estimated with nutrient spiraling metrics (described above in the first paragraph of this section), we also estimated $\mathrm{NO}_{3}{ }^{-}$ removal with simple areal scaling. This approach is commonly used in lentic, wetland, and floodplain systems and when flow conditions in lotic systems are not known (Smith et al. 2000, Poe et al. 2003, David et al. 2006, Sheibley et al. 2006). This technique allowed us to scale our removal estimates to the watershed level, and to examine the importance of flow in load reduction calculations. Under base flow conditions, we calculated $\mathrm{NO}_{3}{ }^{-}$removal as the habitat-weighted areal denitrification rate in the stream $\left(U_{\mathrm{dstr}}\right)$ multiplied by stream area. When the floodplains are inundated, we estimated $\mathrm{NO}_{3}{ }^{-}$ removal as the habitat-weighted areal denitrification rate in both the stream and the floodplains $\left(U_{\mathrm{ddit}}\right)$, multiplied by ditch area.

\section{Statistical analysis}

In accordance with the BACI design, we subtracted the control reach denitrification rate from the treatment reach denitrification rate for each sampling date, and used a $t$ test to determine if the relationship between the control and treatment reaches had changed after the floodplain restoration (Stewart-Oaten et al. 1986). We also used BACI analysis to test for changes in reachscale $\mathrm{NO}_{3}{ }^{-}$removal, $-k, V_{\mathrm{f}, \mathrm{dn}}$, and $S_{\mathrm{w}, \mathrm{dn}}$. We used repeated-measures analysis of variance (RM ANOVA) to determine if there were differences in denitrification rates between substrates or reaches. To determine if instream denitrification was nutrient limited, we performed a two-way ANOVA on the data from the nutrient limitation assays (Tank and Dodds 2003). 
We used simple linear regression to determine relationships between denitrification rates and physicochemical variables. For instream denitrification, these physicochemical variables included surface water $\mathrm{NO}_{3}{ }^{-}$ concentration and sediment organic matter content. For floodplain denitrification, we examined soil exchangeable $\mathrm{NO}_{3}{ }^{-}$concentration, soil gravimetric water content, and soil organic matter content.

We used analysis of covariance (ANCOVA) to determine if the dependence of the simulated storm flow $\mathrm{NO}_{3}{ }^{-}$removal metrics ( $-k$ and $S_{\mathrm{w}, \mathrm{dn}}$,) on $Q$ was different in the trapezoidal vs. two-stage ditch.

We performed most statistical analyses with SYSTAT 12 (SYSTAT Software 2007), and considered $P<0.05$ to be significant. To meet the assumptions of parametric statistics, we tested all data for normality with the Shapiro-Wilk test $(P>0.05)$ and log-transformed the data when necessary. When normality could not be achieved with these transformations, we rank-transformed the data (Iman and Conover 1979). The nonparametric Kendall's Tau test was applied to nonnormal data sets with points below the detection limit (Helsel 2005) using R version 2.11.1 and version 1.5-3 of the NADA package (R Core Development Team 2010).

\section{RESUlts}

\section{Floodplain inundation}

Bank-full events (floodplain inundation), occurred an average of 12 times a year, although there was strong interannual variability in the timing and duration of these events. In 2008, the floodplains were inundated eight separate times, for a total of 29 days. In 2009, the floodplains were inundated 16 separate times, for a total of 132 days. The median duration of each inundation event was 2.5 days, but in the winter and spring of 2009 , they were inundated continuously for 50 days. Prior to restoration, there were $756 \mathrm{~m}^{2}$ of naturally formed floodplains, and after restoration, there were $3520 \mathrm{~m}^{2}$ of floodplains. Because the restored floodplains were constructed at the same height as the naturally formed floodplains, restoration did not increase bank-full channel capacity, nor did it increase the frequency of bank-full events (Kallio 2010a); rather, floodplain restoration increased stream surface area during bankfull events. In addition, floodplain restoration increased average ditch-full cross-sectional area from $8 \mathrm{~m}^{2}$ to 12.5 $\mathrm{m}^{2}$. Ditch-full events occur when water flows out of the ditch and onto the fields, so by increasing ditch-full area, we decreased the frequency of ditch-full events.

\section{Sediment denitrification rates}

The restoration had no effect on instream denitrification rates; the difference between the upstream control and downstream restoration reaches remained consistent across years ( $t$ test of differences, $P>0.75$ ). In general, we found that denitrification rates were higher on FBOM compared to sand, particularly when denitrification was expressed per gram DM (Fig. 2).
Expressing denitrification per gram AFDM (i.e., accounting for differences in organic matter content of the sediment) dampened the differences among substrates, but rates were still higher on FBOM, regardless of the way denitrification was expressed (e.g., g/AFDM, g/ DM, or $\mathrm{m}^{-2}$; RM ANOVA, $P<0.002$ for all tests; Fig. $2 \mathrm{C}$ and $\mathrm{D})$. We found seasonal patterns in instream sediment denitrification rates, with the highest rates measured in the late winter and early spring, and the lowest rates measured in late summer and fall (RM ANOVA, $P<0.002$; Fig. 2). Denitrification rates were 1.5 to 2 times higher in the treatment reach than the control reach on both sand and FBOM, when expressed per gram DM and per $\mathrm{m}^{2}$. Rates were 1.3 times higher in the treatment reach on sand when denitrification was expressed per gram AFDM (RM ANOVAs, $P<0.002$ for all tests; Fig. 2). Over the course of the three-year study, we also found interannual variation in denitrification rates, regardless of how they were expressed, with the lower rates occurring in the last year of our study (RM ANOVA, $P<0.03$ for all tests; Fig. 2).

Warming stream sediments during laboratory incubations resulted in an increase in denitrification rates for all treatments, with the exception of sand during the winter (stream temperature $=1{ }^{\circ} \mathrm{C}$; Fig. 3). Under cool stream temperatures (e.g., winter samples), correcting for incubation temperature resulted in a $40 \%$ decrease in denitrification rates on FBOM (from an average of 0.63 to $0.38 \mu \mathrm{g} \mathrm{N} \mathrm{N}_{2} \mathrm{O}-\mathrm{N} \cdot[\mathrm{g} \mathrm{DM}]^{-1} \cdot \mathrm{h}^{-1}$ ), and a $0 \%$ decrease on sand. Under warm stream temperatures (e.g., summer samples), correcting for temperature resulted in a $10 \%$ decrease in denitrification rates on FBOM (from an average of 0.41 to $0.37 \mu \mathrm{g} \mathrm{N}_{2} \mathrm{O}-\mathrm{N} \cdot[\mathrm{g} \mathrm{DM}]^{-1} \cdot \mathrm{h}^{-1}$ ), and a $30 \%$ decrease in denitrification rates on sand (from an average of 0.13 to $0.09 \mu \mathrm{g} \quad \mathrm{N}_{2} \mathrm{O}-\mathrm{N} \cdot\left[\begin{array}{ll}\mathrm{g} & \mathrm{DM}\end{array}\right]^{-1} \cdot \mathrm{h}^{-1}$ ). However, even when denitrification rates were corrected for incubation temperature, the relationship between reaches remained unchanged (i.e., the $t$ test of differences was still not statistically significant; Fig. 2).

Sediment denitrification rates on FBOM were predicted by surface water $\mathrm{NO}_{3}{ }^{-}$concentrations (SLR with log-transformation, $r^{2}=0.35, P<0.001$; Fig. 4A), and secondarily predicted by sediment organic matter content (SLR with $x$ - and $y$-axis rank-transformation, $r^{2}=0.12, P<0.001$; Fig. 5B). Denitrification rates on sand were predicted by sediment organic matter content (SLR with $y$-axis log-transformation, $r^{2}=0.23, P \mathrm{p}<$ 0.001 ; Fig. 5A), but not by surface water $\mathrm{NO}_{3}{ }^{-}$ concentration (SLR, $r^{2}<0.01, P>0.1$ ).

The nutrient limitation assays demonstrated that the addition of glucose and $\mathrm{NO}_{3}{ }^{-}$significantly increased denitrification rates on only four of 15 sampling dates. Both reaches and substrates were nutrient limited in October 2007, concurrent with low sediment organic matter and water column $\mathrm{NO}_{3}{ }^{-}$, while on the other dates, nutrient limitation occurred in a single reach and substrate, and did not follow a consistent pattern (Table 2). 


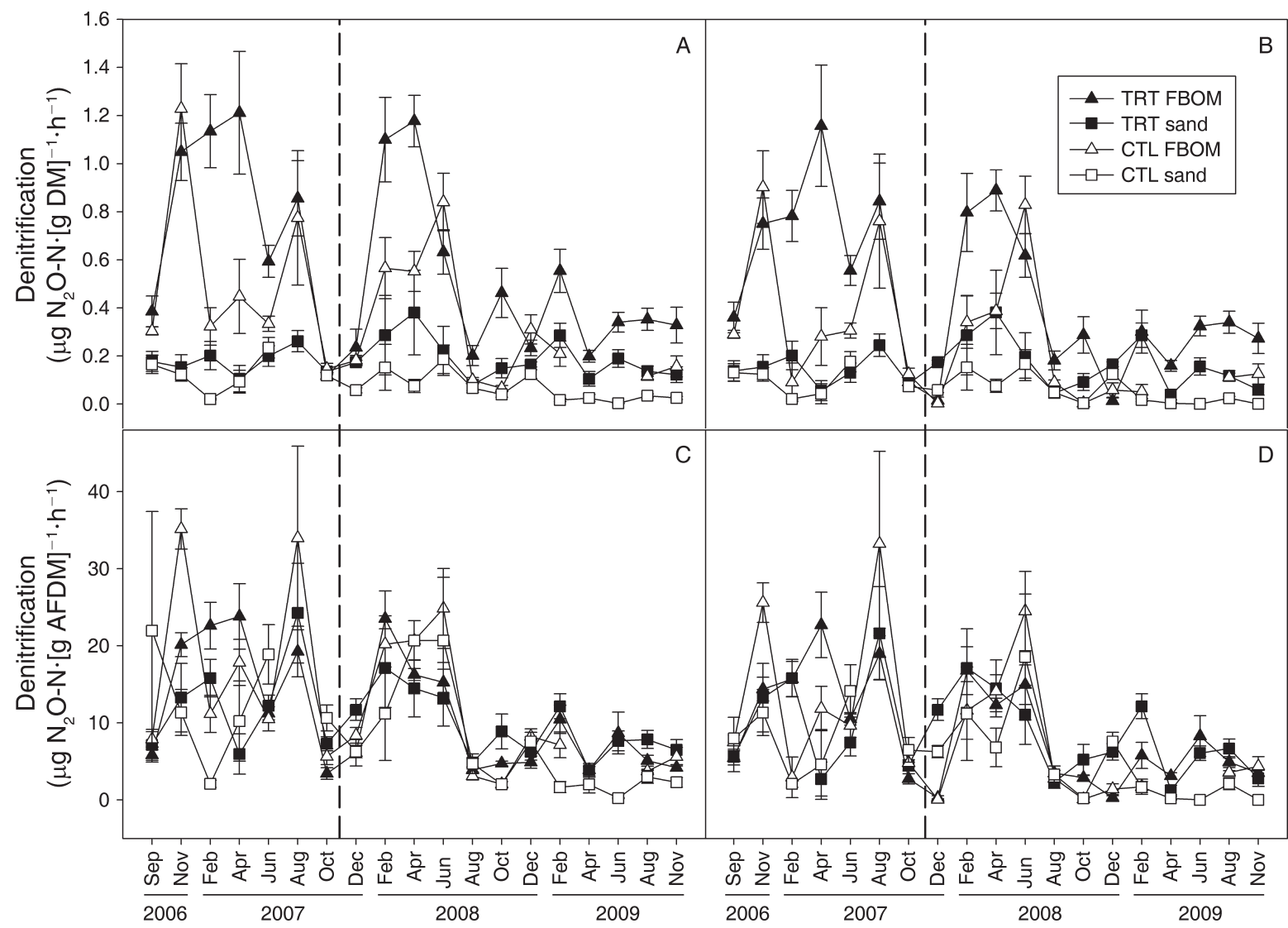

FIG. 2. Denitrification rates in the control (CTL) and treatment (TRT) reaches, on the dominant stream substrate types (sand and fine benthic organic matter $[\mathrm{FBOM}])$. Denitrification is expressed (A) per gram of dry mass (DM), without temperature correction; (B) per gram of DM, corrected for temperature; (C) per gram ash-free dry mass (AFDM), without temperature correction; and (D) per gram AFDM, corrected for temperature. The error bars indicate \pm SE, and the vertical dashed lines indicate the date of the two-stage restoration. Instream denitrification rates exhibited seasonal and interannual variation, but rates were consistently higher in the TRT reach and on FBOM. Correcting for temperature results in slightly lower denitrification rates, but the seasonal patterns remain the same.

\section{Soil denitrification rates on floodplains}

Floodplain denitrification rates from the top $5 \mathrm{~cm}$ of soil ranged from 0.02 to $6.7 \mathrm{mg} \mathrm{N} \mathrm{N}_{2} \mathrm{O}-\mathrm{N} \cdot \mathrm{m}^{-2} \cdot \mathrm{h}^{-1}$, and were significantly lower than instream habitat-weighted rates in the treatment reach (RM ANOVA, $P<0.002$ ), which ranged from 3.2 to $20.3 \mathrm{mg} \mathrm{N} \mathrm{N}_{2} \mathrm{O}-\mathrm{N} \cdot \mathrm{m}^{-2} \mathrm{~h}^{-1}$. Under ambient conditions, the highest rates occurred in the top $5 \mathrm{~cm}$ of the floodplains, but denitrification was observed to $15 \mathrm{~cm}$ depth in nearly all cores (Fig. 6). On average, denitrification in the top $5 \mathrm{~cm}$ represented $56 \%$ $\pm 6 \%($ mean $\pm \mathrm{SE})$ of denitrification measured in the 15 $\mathrm{cm}$ core, and this did not change seasonally (RM ANOVA, $P>0.5$ ).

Mean soil exchangeable $\mathrm{NO}_{3}^{-}$from the floodplain soils was $2.6 \pm 0.3 \mu \mathrm{g} \mathrm{NO}{ }_{3}^{-}-\mathrm{N} / \mathrm{g}$ soil, with a range of below detection $(3 \mu \mathrm{g} / \mathrm{L})$ to $33.7 \mu \mathrm{g} \mathrm{NO}_{3}{ }^{-}-\mathrm{N} / \mathrm{g}$ soil. Soil exchangeable $\mathrm{NO}_{3}{ }^{-}$was correlated with floodplain soil denitrification rates (Kendall's tau, $\tau=0.34, P<0.001$; Fig. 7), but denitrification in floodplain soils was measurable even when soil exchangeable $\mathrm{NO}_{3}{ }^{-}$was below detection. Surface water $\mathrm{NO}_{3}^{-}$concentration did not predict denitrification in laboratory assay samples experimentally saturated with stream water (SLR, $r^{2}=$ $0.02, P>0.1)$. In fact, the addition of stream water to floodplain soils in the laboratory stimulated denitrification only on the last sampling date, in November 2009 ( $t$ test, $P<0.05$; Fig. 6 ). In addition, the soil denitrification rates measured during naturally flooded conditions (February 2008) were within the range measured under laboratory inundations (Fig. 6).

Soil organic matter content averaged $7.8 \% \pm 0.3 \%$ (range: $0.7-32 \%$ ), and was a weak predictor of soil denitrification when surface water was not added (SLR, $\left.r^{2}=0.06, P<0.02\right)$. Soil gravimetric water content from floodplains averaged $42 \% \pm 1 \%$, but was quite variable in space (range: 13-67\%) and was not a significant predictor of floodplain denitrification rates (SLR, $r^{2}=$ $0.01, P>0.3)$. The carbon quality index, calculated as the molar ratio of $\mathrm{CO}_{2}$ production rate to $\mathrm{N}_{2} \mathrm{O}$ production rate, was significantly higher on the floodplains compared to stream sediments (RM ANOVA, $P$ $<0.001$; Fig. 8). 


\section{Nitrogen removal via denitrification}

Base flow $\mathrm{NO}_{3}{ }^{-}$removal rate $(-k)$ within the stream channel averaged $15 \pm 1$ percentage per day, with a range of $5 \%$ to $29 \%$ (Fig. 9A), and did not change postfloodplain construction, relative to the control reach $(t$ test of differences, $P>0.2$; Fig. 9A). In addition, $\mathrm{NO}_{3}{ }^{-}$ uptake velocity via denitrification $\left(V_{\mathrm{f}, \mathrm{dn}}\right)$ did not change post-construction ( $t$ test of differences, $P>0.6$ ), and neither did the variables used to calculate $V_{\mathrm{f}, \mathrm{dn}}$ (denitrification and $\mathrm{NO}_{3}{ }^{-}$concentration; see Methods: Reach-scale $\mathrm{NO}_{3}{ }^{-}$removal calculations). Finally, the $\mathrm{NO}_{3}{ }^{-}$uptake length $\left(S_{\mathrm{W}, \mathrm{dn}}\right)$ in the stream channel at base flow did not change post-restoration ( $t$ test of differences, $P>0.16)$, and fell within the range measured in agricultural stream channels reported in previous studies (Table 3; Royer et al. 2004, Mulholland et al. 2009).

In contrast to base flow conditions, under simulated storm conditions that would result in the inundation of floodplains, $\mathrm{NO}_{3}{ }^{-}$loss $(-k)$ was typically higher in the two-stage ditch than the trapezoidal channel (Fig. 9B). As stream flows increased, $-k$ decreased, because $\mathrm{NO}_{3}{ }^{-}$ load increases with discharge. However, the rate of decrease in $-k$ with increasing $Q$ was lower in the twostage compared to the trapezoidal channel (ANCOVA of 2008 data, $P<0.01$; ANCOVA of 2009 data, $P<$ 0.03; Fig. 9B); therefore, the two-stage ditch dampens storm flow $\mathrm{NO}_{3}{ }^{-}$export. Similarly, the denitrification uptake length $\left(S_{\mathrm{w}, \mathrm{dn}}\right)$ during storm flow was always lower in the two-stage, compared to the trapezoidal, channel, indicating that $\mathrm{NO}_{3}{ }^{-}$is denitrified closer to its point of entry into the stream channel and does not travel as far when the two-stage ditch is present. Therefore, although the two-stage ditch had minimal influence on water column $\mathrm{NO}_{3}{ }^{-}$removal during base flow, it did reduce storm flow $\mathrm{NO}_{3}{ }^{-}$export.

Estimates of $\mathrm{NO}_{3}{ }^{-}$loss with the areal scaling method were lower than with nutrient spiraling, but exhibited the same patterns. Base flow $\mathrm{NO}_{3}{ }^{-}$removal averaged $1.3 \% \pm 0.2 \%$ per day (range: $0.3-2.3 \%$ ) with areal scaling, compared to $15 \pm 1$ percentage per day (range: 5-29\%) calculated with nutrient spiraling. Under simulated storm flows, $\mathrm{NO}_{3}{ }^{-}$loss averaged $0.5 \% \pm 0.09 \%$ per day (range: $0.3-0.8 \%$ ) with areal scaling and $6.1 \% \pm$ $0.4 \%$ per day (range: $5.0-7.8 \%$ ) with nutrient spiraling.

\section{Discussion}

We completed a multiyear assessment of a novel, reach-scale stream restoration technique in a midwestern agricultural stream. This sort of analysis is rare but necessary for proper evaluation of stream restorations (Bernhardt et al. 2005, Palmer et al. 2007), and provides important insights into the utility of the two-stage ditch restoration practice. Our statistical design (BACI) was critical for separating the influence of interannual variation from the influence of the two-stage ditch, because there were pre-existing differences between the control and treatment reaches, as well as interannual variation in denitrification rates.

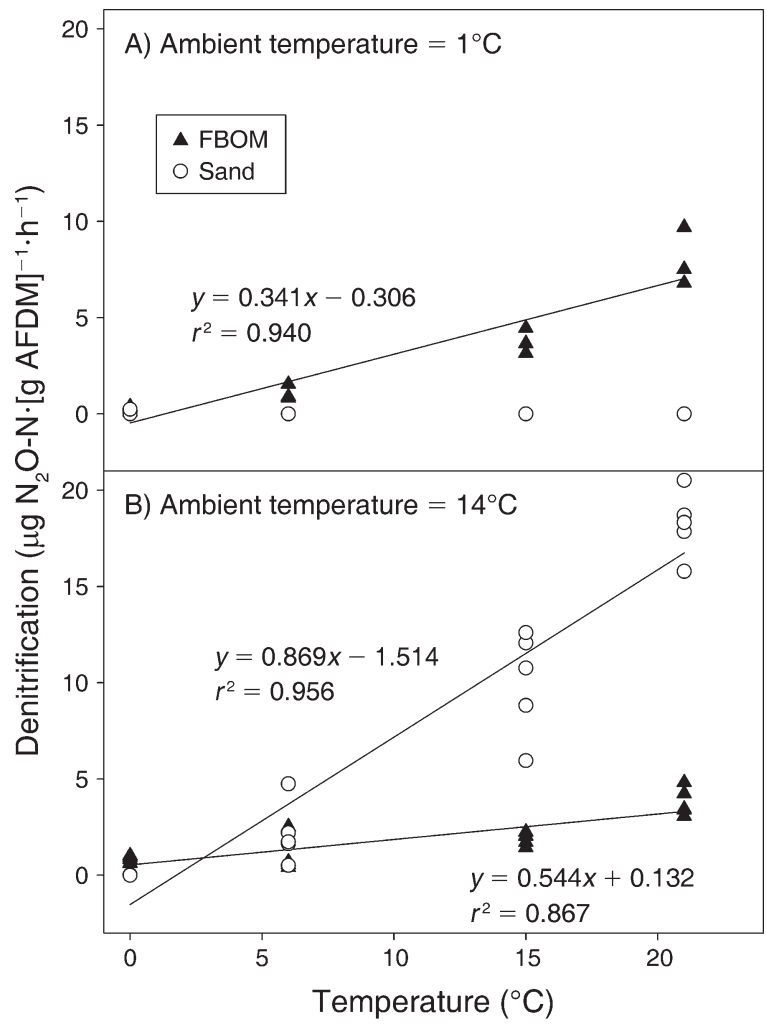

FIG. 3. The effect of laboratory incubation temperature on denitrification rates supported by sand and FBOM, under (A) cool and (B) warm ambient stream water temperatures. Regression equations are displayed only when the regression was statistically significant $(P<0.5)$. The effect of temperature varied by season and substrate.

We observed large interannual variation in floodplain inundation frequency and duration. Greater $\mathrm{NO}_{3}{ }^{-}$ export generally occurs during high-precipitation years than during low-precipitation years (Royer et al. 2006), but high precipitation will also result in increased floodplain-water column contact time. As a result, we expect that the influence of the two-stage ditch on $\mathrm{NO}_{3}{ }^{-}$ export will vary substantially from year to year, and that the greatest relative reduction in $\mathrm{NO}_{3}{ }^{-}$export will occur during wet years.

\section{Controls on denitrification rates}

The restoration of floodplains did not compromise instream denitrification rates, which remained high throughout the three-year study period (Fig. 2), indicating that the $\mathrm{NO}_{3}{ }^{-}$removal capacity of the stream channel was maintained. In contrast, there is some evidence that floodplain construction can influence instream sediment characteristics over the long term (i.e., years): The main stream channel tends to narrow, which increases water velocities (Powell et al. 2007), and can result in the removal of lighter FBOM particles, changing the stream bed to predominantly sand bottom. Since sand supports lower denitrification rates than 

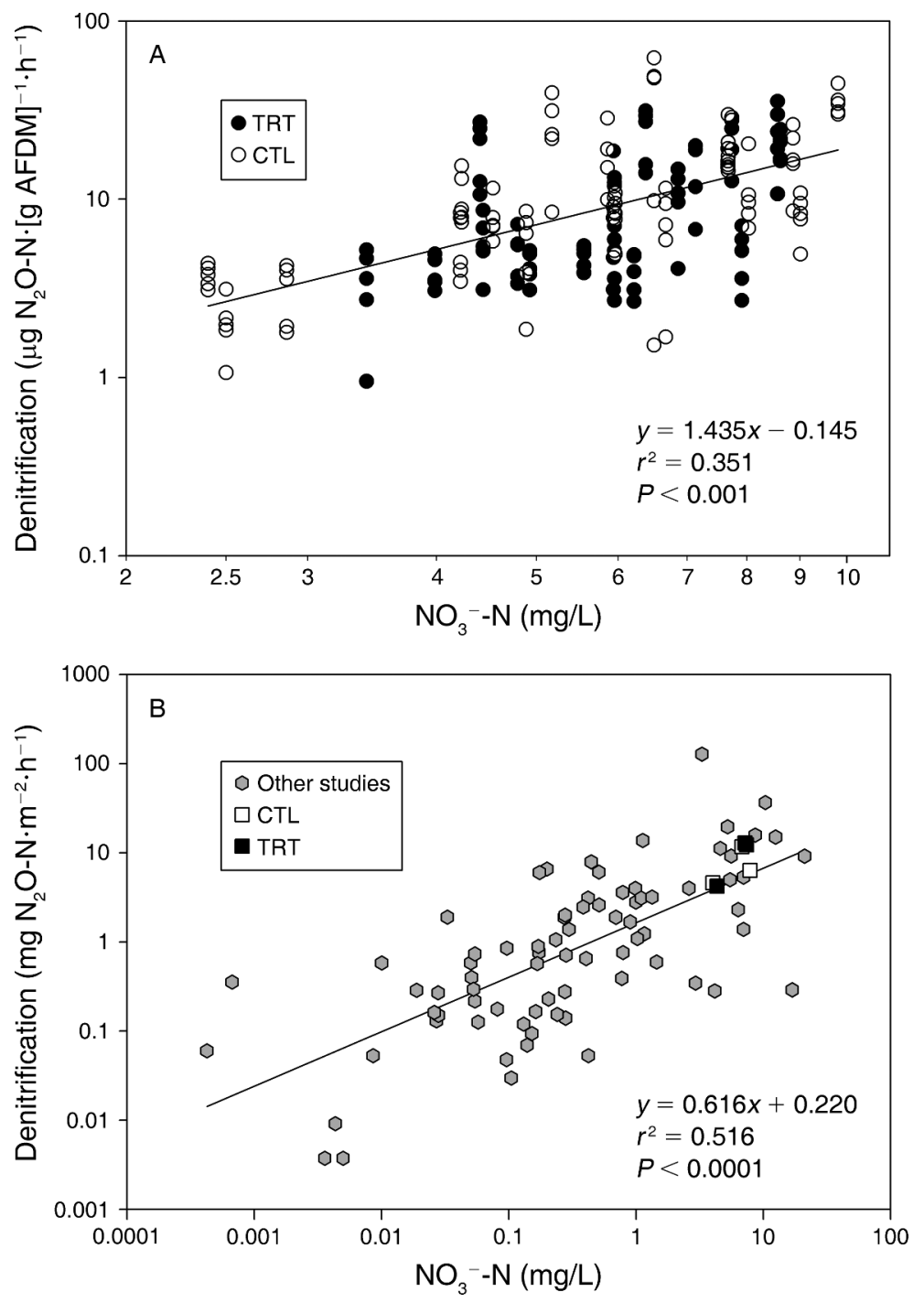

FIG. 4. (A) Relationship between instream denitrification rates on fine benthic organic matter (FBOM) and stream water $\mathrm{NO}_{3}^{-}$ concentration. Each data point represents the denitrification rates measured in one of five replicate samples collected on each sampling date. The relationship between instream denitrification rates and stream water $\mathrm{NO}_{3}{ }^{-}$was not significant in sand. (B) Whole-stream, habitat-weighted denitrification rates and stream water $\mathrm{NO}_{3}{ }^{-}$concentrations in Shatto Ditch, compared with previously published data from other systems. Denitrification rates were measured with many methods, including whole-stream ${ }^{15} \mathrm{NO}_{3}{ }^{-}$releases, membrane inlet mass spectrometry (MIMS), in situ $\mathrm{C}_{2} \mathrm{H}_{2}$ block chambers, and laboratory $\mathrm{C}_{2} \mathrm{H}_{2}$ slurries (Triska and Oremland 1981, Duff et al. 1984, Christensen et al. 1990, Nielsen et al. 1990, García-Ruiz et al. 1998, Pattinson et al. 1998, Bernhardt and Likens 2002, Kemp and Dodds 2002, Böhlke et al. 2004, Laursen and Seitzinger 2004, Mulholland et al. 2004, 2008, Royer et al. 2004, Schaller et al. 2004, Inwood et al. 2005, Pribyl et al. 2005, Arango et al. 2007). Each point in Shatto represents the seasonal average (winter, spring, and summer/fall) within the control or treatment reach. Note that some of the Shatto Ditch points overlap. Both denitrification rates and stream water $\mathrm{NO}_{3}{ }^{-}$concentrations in Shatto Ditch were among the highest reported in the literature. Note the $\log -\log$ scale plots.

FBOM, the result would likely be lower reach-scale denitrification rates. However, we did not observe a decrease in FBOM throughout our study; thus, if this is a trend, it may take longer than two years postconstruction to become apparent.

Previous research has demonstrated that sediment microbial denitrification rates are best predicted by stream water $\mathrm{NO}_{3}{ }^{-}$concentrations (Pina-Ochoa and Alvarez-Cobelas 2006, Mulholland et al. 2009), and results from this study are consistent with these prior results (Fig. 4B). Yet agricultural streams may also represent unique cases in that $\mathrm{NO}_{3}{ }^{-}$concentrations routinely reach a threshold beyond which denitrification is no longer $\mathrm{NO}_{3}{ }^{-}$limited (Inwood et al. 2005, Wall et al. 2005). The exact value of this threshold varies among systems and is likely related to sediment quality and availability of alternative electron acceptors. Stream water $\mathrm{NO}_{3}^{-}$concentrations in this study apparently 

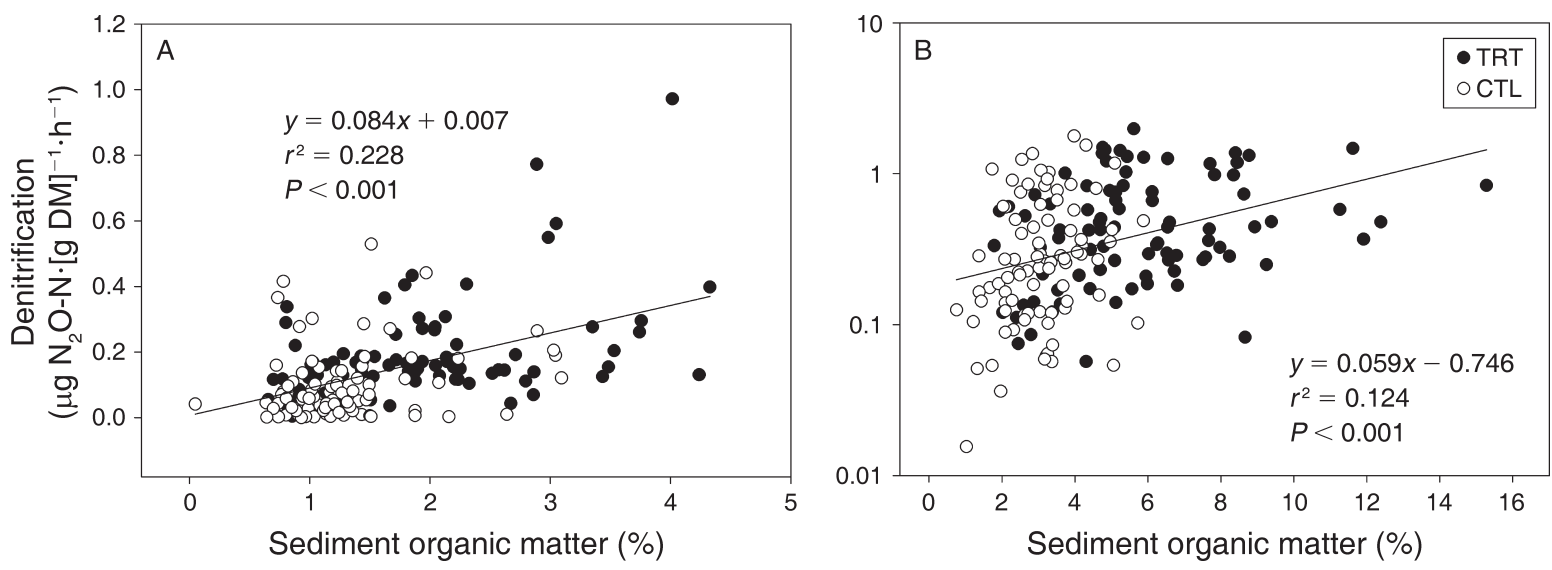

FIG. 5. Relationship between sediment organic matter content and denitrification rate on (A) sand and (B) fine benthic organic matter (FBOM) with log scale for denitrification.

exceeded the threshold value for denitrification supported by sand, as evidenced by the lack of relationship between denitrification on sand and surface water $\mathrm{NO}_{3}{ }^{-}$ concentration. The threshold value was apparently not exceeded on FBOM, probably as a result of high carbon availability (Arango et al. 2007) and increased surface area for microbial colonization of the finer particles associated with FBOM (Inwood et al. 2007).

The response of denitrifiers to temperature varied by substrate and season. Under cold ambient stream temperatures, warming had no effect on denitrification rates on sand, but slightly stimulated denitrification on FBOM (Fig. 3). Under warm ambient stream temperatures, the effect of temperature was more pronounced (Fig. 3), but because the stream temperature was closer to the incubation temperature, correcting for the difference had only a small effect on denitrification rates. Thus, the combined adjustments during both cold and warm sampling resulted in somewhat dampened seasonal trends in denitrification rates, yet seasonal patterns remained apparent (Fig. 2). In summary, seasonal changes in surface water $\mathrm{NO}_{3}{ }^{-}$concentration and sediment organic matter content are responsible for much of the variability in denitrification rates.

In contrast to stream sediments, denitrification rates in restored floodplains are consistently controlled by soil organic matter content (Groffman and Crawford 2003, Sheibley et al. 2006, Orr et al. 2007, Gift et al. 2010), although the strength of the relationship varies substantially. Previously published relationships between denitrification and other soil variables are less consistent; soil nitrogen, soil moisture, and root biomass all predicted denitrification to some degree in some systems (Sheibley et al. 2006, Gift et al. 2010). In this study, floodplain denitrification rates were controlled by soil-exchangeable $\mathrm{NO}_{3}{ }^{-}$(Fig. 7) and weakly controlled by soil organic matter content. Floodplain denitrification rates were less predictable than instream rates, but floodplains are more spatially and temporally variable than streams (Naiman et al. 1988, Hedin et al. 1998).

TABLE 2. Denitrification rates (mean $\pm \mathrm{SE}$ ) per treatment on dates and substrates in which nutrient limitation occurred.

\begin{tabular}{cccccc}
\hline \hline & & \multicolumn{3}{c}{ Denitrification rate $\left(\mu \mathrm{g} \mathrm{N} \mathrm{N}_{2} \mathrm{O}-\mathrm{N} \cdot[\mathrm{g} \mathrm{DM}]^{-1} \cdot \mathrm{h}^{-1}\right) \dagger$} \\
\cline { 3 - 6 } Date and reach & Substrate & 0 & $\mathrm{~N}$ & $\mathrm{C}$ & $\mathrm{NC}$ \\
\hline 2007 & & & & & \\
Oct CTL & sand & $0.12 \pm 0.02$ & $0.16 \pm 0.02$ & $\mathbf{0 . 2 4} \pm \mathbf{0 . 0 2}$ & $0.25 \pm 0.06$ \\
Oct CTL & FBOM & $0.15 \pm 0.02$ & $\mathbf{0 . 2 4} \pm \mathbf{0 . 0 4}$ & $\mathbf{0 . 2 7} \pm \mathbf{0 . 0 6}$ & $\mathbf{0 . 3 9} \pm \mathbf{0 . 0 3}$ \\
Oct TRT & sand & $0.13 \pm 0.01$ & $\mathbf{0 . 1 6} \pm \mathbf{0 . 0 1}$ & $\mathbf{0 . 1 7} \pm \mathbf{0 . 0 2}$ & $\mathbf{0 . 2 5} \pm \mathbf{0 . 0 1}$ \\
Oct TRT & FBOM & $0.12 \pm 0.01$ & $\mathbf{0 . 1 7} \pm \mathbf{0 . 0 3}$ & $\mathbf{0 . 1 4} \pm \mathbf{0 . 0 2}$ & $\mathbf{0 . 3 8} \pm \mathbf{0 . 0 7}$ \\
2008 & & & & & \\
Feb TRT & FBOM & $1.10 \pm 0.18$ & $\mathbf{2 . 0 6} \pm \mathbf{0 . 1 5}$ & $1.11 \pm 0.08$ & $1.94 \pm 0.20$ \\
Apr TRT & FBOM & $1.18 \pm 0.11$ & $\mathbf{1 . 8 1} \pm \mathbf{0 . 1 5}$ & $1.30 \pm 0.20$ & $1.84 \pm 0.20$ \\
2009 & & & & & \\
Aug CTL & FBOM & $0.12 \pm 0.02$ & $\mathbf{0 . 1 7} \pm \mathbf{0 . 0 2}$ & $0.09 \pm 0.01$ & $0.15 \pm 0.01$
\end{tabular}

Notes: Abbreviations are: CTL, control reach; TRT, treatment reach; and FBOM, fine benthic organic matter. Numbers in boldface indicate significant $(P<0.05)$ nutrient limitation, according to a two-way ANOVA from Tank and Dodds (2003).

$\dagger$ Treatments are: 0 , control, no nutrient amendments; $\mathrm{N}$, nitrate added, as $\mathrm{KNO}_{3}{ }^{-} ; \mathrm{C}$, carbon added, as glucose; and NC, nitrate and carbon added. 


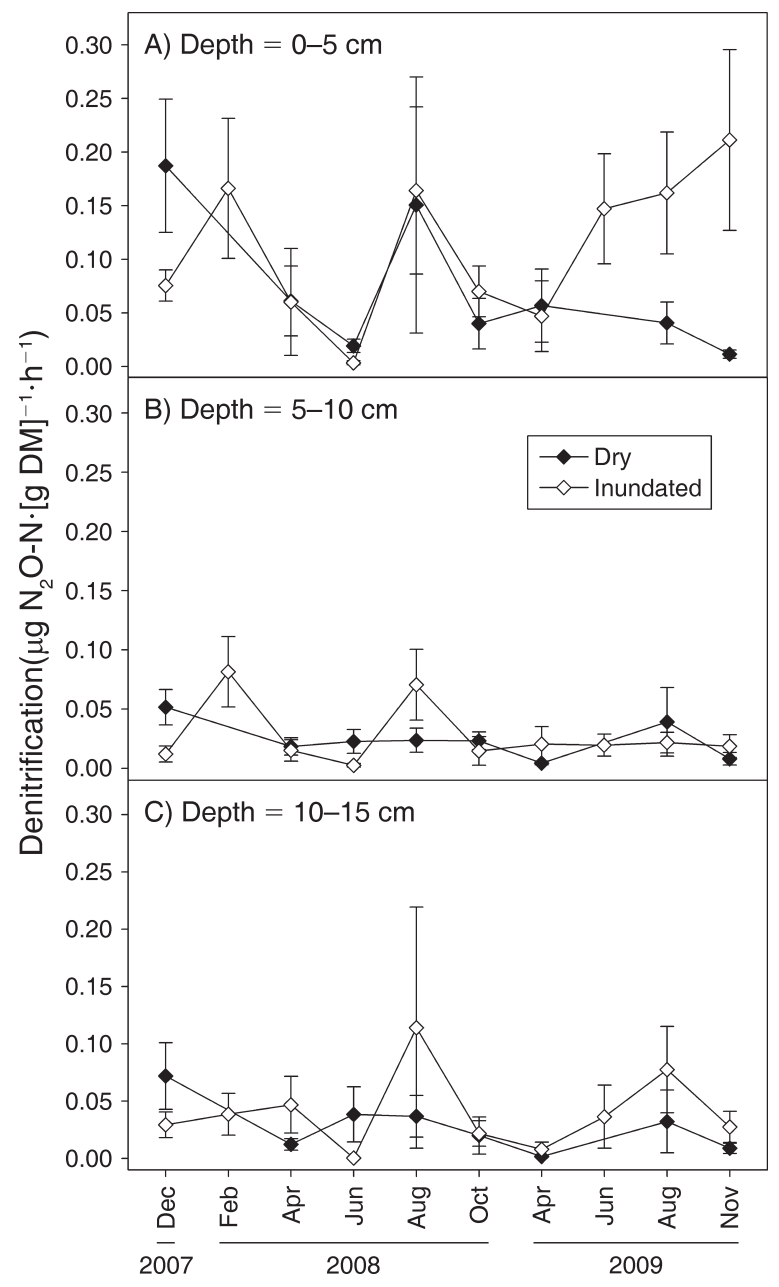

FIG. 6. Post-restoration floodplain denitrification rates by stratum and incubation type. Samples were either incubated with surface water added (Inundated) or at field moisture, without any surface water added (Dry). Error bars are standard error. The highest denitrification rates occurred in the top $5 \mathrm{~cm}$, although denitrification was measurable to $15 \mathrm{~cm}$. The addition of stream water stimulated denitrification rates only on the final sampling period.

Post-restoration, soil denitrification was measurable on the floodplains almost immediately after construction and did not change significantly after the first sampling date (Fig. 6), suggesting that denitrifying microbes were either already present or colonized rapidly. Denitrification rates were consistently lower on floodplain soils compared to stream sediments, especially FBOM. This may be due, in part, to differences in carbon quality (Fig. 8), but may be also explained by differences in oxygen availability or in the microbial community colonizing particles. Floodplain soil denitrification did not respond to the addition of stream water, perhaps because (1) the microbes on floodplain soils were not limited by $\mathrm{NO}_{3}^{-}$, (2) the addition of chloramphenicol did not allow the microbes to take advantage of the influx of $\mathrm{NO}_{3}{ }^{-}$, or (3) carbon on the floodplains was not of sufficiently high quality.

\section{Contribution of the two-stage restoration to nitrogen removal}

We found no change in base flow $\mathrm{NO}_{3}^{-}$removal, because the construction of stream-side floodplains did not affect instream denitrification rates (Figs. 2 and 9A). However, our estimates of base flow $\mathrm{NO}_{3}{ }^{-}$removal are conservative, because they assume that floodplains do not contribute to stream water $\mathrm{NO}_{3}{ }^{-}$removal unless they are inundated. At Shatto Ditch, the floodplains were created from a grass buffer strip, and the surrounding fields are drained with subsurface tiles, which convey high- $\mathrm{NO}_{3}{ }^{-}$groundwater from fields directly to the stream, allowing minimal opportunity for N processing (Fennessy and Cronk 1997, Ducros and Joyce 2003). In contrast, the floodplains are a part of the stream corridor and close to the water table. As a result, the soils are more saturated and have more anoxic microsites, which are necessary for denitrification. In addition, the floodplains receive $\mathrm{NO}_{3}{ }^{-}$inputs from tile drains, periodic surface water inundations, soil nitrification, and hyporheic flow. Therefore, the constructed floodplains support higher denitrification rates than the buffer strip (M. L. Stephen, unpublished data), likely reducing the $\mathrm{NO}_{3}{ }^{-}$load entering the stream.

In our calculations, we only used denitrification rates from the surface layer $(0-2 \mathrm{~cm}$ in the stream, $0-5 \mathrm{~cm}$ on the floodplains) because (1) this method allows direct comparison to previous stream studies (e.g., Christensen et al. 1990, Royer et al. 2004, Arango et al. 2007), and (2) we used the rates to estimate nutrient spiraling metrics. Nutrient spiraling only accounts for the surface sediments, because they interact directly with surface water. We found that denitrification rates decreased with depth in the floodplain soils, but the top layer only accounted for $56 \%$ of total denitrification, indicating that there is substantial $\mathrm{N}$ removal potential at depth.

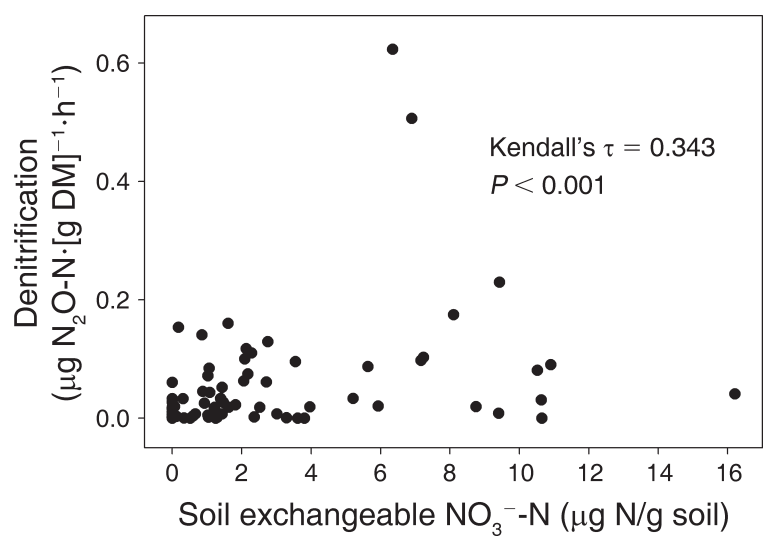

FIG. 7. Relationship between denitrification rates on floodplain soils (incubated without the addition of stream water) and soil exchangeable $\mathrm{NO}_{3}{ }^{-}$concentration. 


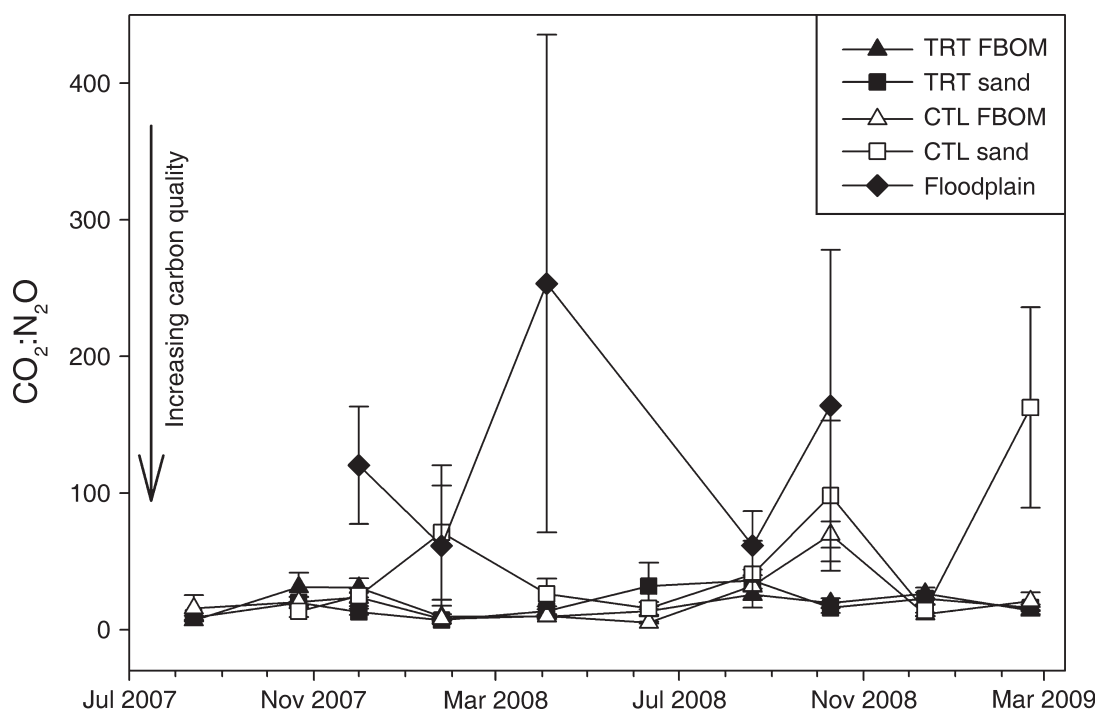

FIG. 8. Ratio of carbon dioxide $\left(\mathrm{CO}_{2}\right)$ to nitrous oxide $\left(\mathrm{N}_{2} \mathrm{O}\right)$ sediment production rates during denitrification assays, an index of carbon quality, through time. Data are grouped by reach type (i.e., treatment [TRT] or control [CTL]) and sediment type (i.e., fine benthic organic matter $[\mathrm{FBOM}]$ or sand). Floodplain denitrification rates were from samples incubated with stream water.

Similarly, we found that the top $2 \mathrm{~cm}$ of stream sediment supported $44 \%$ of the denitrification observed throughout a $20 \mathrm{~cm}$ core (S. S. Roley, unpublished data), suggesting that our estimates of reach-scale denitrification are conservative because they don't account for denitrification activity on deeper material.

Storm flow $\mathrm{NO}_{3}{ }^{-}$removal was higher in the two-stage ditch than the trapezoidal channel (Fig. 9B), indicating that the two-stage ditch can reduce $\mathrm{NO}_{3}{ }^{-}$loads during high flows, which is when agricultural streams export the most $\mathrm{NO}_{3}{ }^{-}$(Royer et al. 2006). The magnitude of the increase was strongly influenced by the denitrification rate in the floodplains, because when the ditch was fully flooded, the majority of benthic surface area was floodplain soils. On an annual basis, the influence of the floodplains also depended upon the length of time they were inundated. In 2008, floodplain inundation was minimal (29 days), and the floodplains contributed only $12 \%$ of the annual ditch $\mathrm{N}$ removal (Table 4 ). In contrast, in 2009, the floodplains contributed $47 \%$ of the annual ditch $\mathrm{N}$ removal, both because of extended inundation and a higher median denitrification rate (Table 4). The success of two-stage ditches at retaining $\mathrm{N}$ will depend upon the quality of floodplain substrate for denitrification, and the elevation of the restored floodplains, which controls inundation frequency.

Denitrification uptake length $\left(S_{\mathrm{w}, \mathrm{dn}}\right)$ was shorter in the two-stage ditch than in the trapezoidal channel
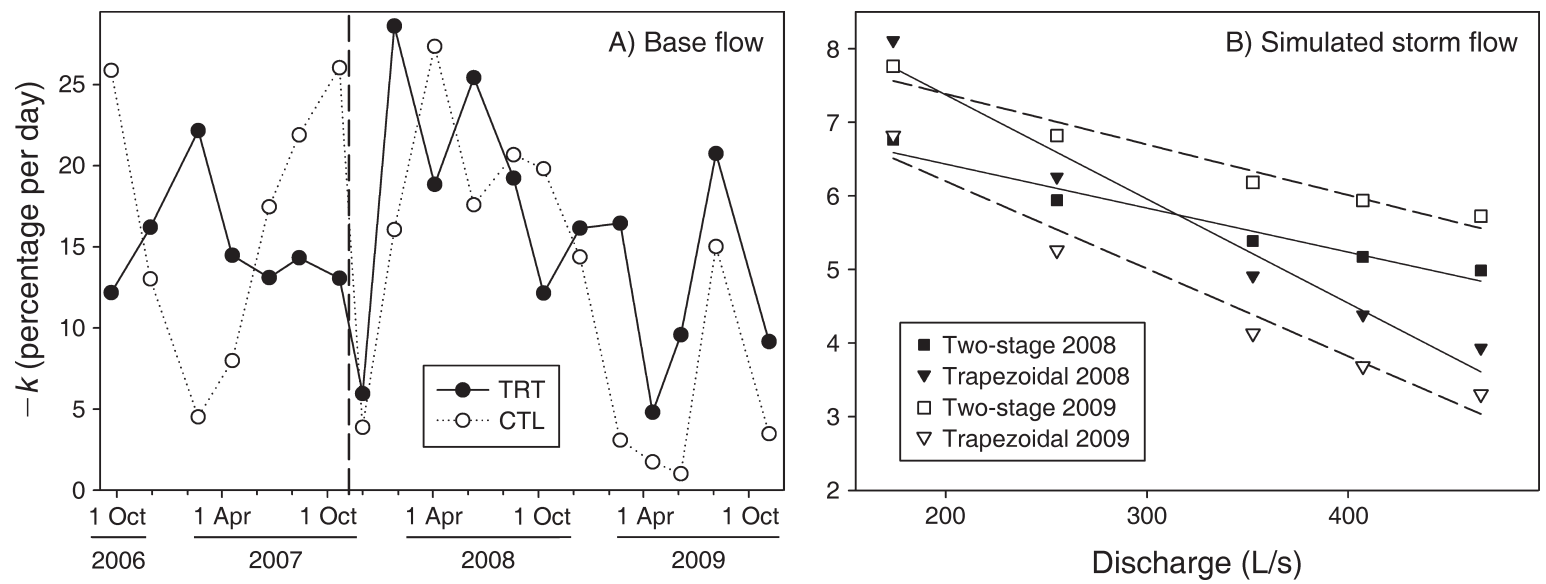

FIG. 9. Percentage of the $\mathrm{NO}_{3}{ }^{-}$load removed per day $(-k)$ (A) under base flow conditions and (B) under simulated storm flow conditions. (A) The dotted line indicates the date of two-stage construction. (B) Simulated storm flow was calculated with the median denitrification rates from 2008 and 2009. There was a significant difference, by ANCOVA, in the slopes of the regression lines for 2008 data (solid lines, $P<0.01$ ) and 2009 data (dashed lines, $P<0.05$ ). 
TABle 3. Denitrification uptake length $\left(S_{\mathrm{w}, \mathrm{dn}}\right)$ in this study and other studies of agriculturally influenced streams.

\begin{tabular}{lcr}
\hline \hline \multirow{2}{*}{\multicolumn{1}{c}{ Source }} & \multicolumn{2}{c}{$S_{\mathrm{w}, \mathrm{dn}}(\mathrm{km})$} \\
\cline { 2 - 3 } & Lowest & Highest \\
\hline Mulholland et al. (2009) & 1 & 184 \\
Royer et al. (2004) & 8 & $>200$ \\
This study & 21 & 152 \\
$\quad$ Base flow & 42 & 218 \\
Two-stage storm flow & 56 & 320 \\
Storm flow (no two-stage) & & \\
\hline
\end{tabular}

(Table 3); on average, $\mathrm{NO}_{3}{ }^{-}$in the water column of a two-stage ditch does not travel as far prior to denitrification as does $\mathrm{NO}_{3}{ }^{-}$from a trapezoidal channel. Shatto Ditch is a high- $\mathrm{NO}_{3}{ }^{-}$stream, even for an agriculturally influenced system $\left(\mathrm{NO}_{3}{ }^{-}\right.$concentration ranged from 2-9 $\mathrm{mg} \mathrm{NO}_{3}{ }^{-} \mathrm{N} / \mathrm{L}$ ), so our estimates of two-stage ditch potential are likely conservative: In a lower $\mathrm{NO}_{3}^{-}$system, higher $\mathrm{NO}_{3}^{-}$removal efficiencies may be achieved.

Although floodplain construction via the two-stage ditch dampens storm flow $\mathrm{NO}_{3}{ }^{-}$export, at least $90 \%$ of the load was still exported in all storm flow scenarios (Fig. 9B). Under base flow conditions, maximum $\mathrm{NO}_{3}{ }^{-}$ removal was $28 \%$, which occurred when the $\mathrm{NO}_{3}{ }^{-}$load was relatively low $(41 \mathrm{~kg} / \mathrm{d})$. Across a gradient of land use, stream $\mathrm{N}$ removal efficiencies in a multi-biome study of 72 headwater streams varied from $0.5 \%$ to $100 \%$ (Mulholland et al. 2008, 2009), with the highest removal efficiencies relative to $\mathrm{N}$ loading occurring under the lowest $\mathrm{NO}_{3}{ }^{-}$loads. Thus, even though twostage ditch restoration enhanced reach-scale $\mathrm{N}$ removal at Shatto Ditch, it is unlikely to substantially reduce $\mathrm{NO}_{3}{ }^{-}$loads unless landscape management practices that reduce stream $\mathrm{NO}_{3}{ }^{-}$inputs from upland fields are also adopted (Craig et al. 2008).

\section{Two-stage ditch influence at the sub-watershed scale}

All of our reach-scale calculations of $\mathrm{NO}_{3}{ }^{-}$removal were based on our $600-\mathrm{m}$ study reach, but additional $\mathrm{NO}_{3}{ }^{-}$removal benefit may be achieved by increasing the length of restored floodplains. The floodplains along the 600 -m treatment reach in this study occupy $<0.04 \%(0.4$ ha) of the upstream watershed area (1036 ha) and 7\% of the total drainage network length (Fig. 1B). To examine the potential for widespread implementation of two-stage ditches to reduce $\mathrm{NO}_{3}{ }^{-}$loads, we developed a model that integrates drainage network, channel morphology, and hydrology data with measured denitrification rates for the stream sediments and floodplain soils, as well as the additional stream surface area created during storms (J. D. Witter, unpublished method). This method accounts for changes in surface area, but not water residence time, so it results in lower $\mathrm{NO}_{3}{ }^{-}$removal estimates than those calculated with the nutrient spiraling method. Nonetheless, it offers an estimate of the relative increase in $\mathrm{NO}_{3}{ }^{-}$removal.
To estimate $\mathrm{NO}_{3}{ }^{-}$removal at a sub-watershed scale, we evaluated several scenarios which varied the percentage of the drainage network in two-stage ditch treatment $(7 \%, 50 \%$, and $100 \%$ of the drainage network) and applied the median denitrification rates from 2008 and 2009 (Table 4) to estimate annual $\mathrm{NO}_{3}{ }^{-}$load reductions if the length of two-stage ditch were extended beyond this experiment's $600-\mathrm{m}$ treatment. Denitrification in the stream channel was simulated for the entire year and estimates of floodplain denitrification were limited to days when the floodplains were inundated with surface water. Results of the analysis suggest that if all of the stream length in the Shatto Ditch sub-watershed were placed in two-stage, the addition of the floodplains would be capable of removing $10-11 \%$ of the annual $\mathrm{NO}_{3}{ }^{-}$load, compared to $6-9 \%$ of the annual load when only $600 \mathrm{~m}$ is restored (Table 4).

\section{Comparison to other best management practices}

Floodplains can form naturally in unmaintained ditches, particularly when the channel is wider than necessary (Landwehr and Rhoads 2003), but their formation occurs slowly over a long period of channel instability. In addition, surface area is limited to the original channel width (i.e., no surface area is added). In contrast, the construction of floodplains associated with the two-stage ditch restoration results in immediate improvement in channel stability and an increase in bioreactive surface area. Microbial denitrification occurs on soils in both constructed and naturally formed floodplains (Powell and Bouchard 2010), but we believe that the larger surface area and immediate benefits

TABLE 4. (a) Annual load reductions achieved with two-stage ditch and (b) potential load reductions achieved by extending the two-stage ditch.

\begin{tabular}{lrr}
\hline a) Data used for scaling up: & & \\
\multicolumn{1}{c}{ Scenario description } & 2008 & 2009 \\
\hline Median instream denitrification $\dagger$ & 9.5 & 5.9 \\
Median floodplain denitrification $\dagger$ & 3.1 & 6.1 \\
Duration of floodplain inundation (d) & 29 & 132 \\
Annual instream N removal & 162 & 100 \\
Annual floodplain N removal§ & 21 & 89
\end{tabular}

b) Results of the scaling:

\begin{tabular}{ccccr}
\multicolumn{2}{c}{ Two-stage extent } & & \multicolumn{2}{c}{$\begin{array}{c}\text { Total network } \\
\text { load reduction }(\%)\end{array}$} \\
\cline { 1 - 1 } \cline { 5 - 5 } Length $(\mathrm{km})$ & $\begin{array}{c}\text { Percentage } \\
\text { of watershed }\end{array}$ & & 2008 & 2009 \\
\hline 0.6 & 7 & & 8.9 & 5.9 \\
4.1 & 50 & & 9.5 & 7.9 \\
8.4 & 100 & & 10.0 & 10.3 \\
\hline
\end{tabular}

Notes: Model estimates using the median channel and floodplain denitrification rates are shown. Note that two-stage ditch effectiveness increases with ditch length, and is strongly influenced by denitrification rate and duration of inundation.

$\dagger$ Denitrification rate in $\mathrm{mg} \mathrm{N} \cdot \mathrm{m}^{-2} \cdot \mathrm{h}^{-1}$.

$\$ \mathrm{~N}$ removal via denitrification, in $\mathrm{kg} \mathrm{N} / \mathrm{yr}$.

$\S \mathrm{N}$ removal via denitrification, when floodplains are inundated, in $\mathrm{kg} \mathrm{N} / \mathrm{yr}$. 
associated with two-stage restoration make it preferable to naturally formed floodplains.

Another widely recommended BMP is constructed wetlands (Mitsch et al. 2001), whose soils typically have redox conditions that are ideal for denitrification, and whose relatively long water residence time can result in high N removal efficiencies (Mitsch et al. 2005, Borin and Tocchetto 2007). However, wetlands are less effective during storm flows, when their water holding capacity is overwhelmed (Kovacic et al. 2000, 2006). Wetlands and two-stage ditches are potentially complementary BMPs, with wetlands intercepting base flow tile drain water, and two-stage ditches accommodating storm flow and increasing $\mathrm{NO}_{3}{ }^{-}$removal rates during floodplain inundation. Further investigation into optimal complementary placement of these surface water BMPs is warranted.

The $\mathrm{N}$ removal efficiencies of wetlands, streams, and two-stage ditches generally decrease with $\mathrm{N}$ load (Mitsch and Gosselink 2000, Mulholland et al. 2008, 2009). Agriculturally influenced streams (including Shatto Ditch) are notoriously high in $\mathrm{NO}_{3}{ }^{-}$(Osborne and Wiley 1988, Johnson et al. 1997, Stanley and Maxted 2008), and as a result, we do not expect that two-stage ditches or constructed wetlands will completely alleviate downstream $\mathrm{N}$ loading problems. Instead, we recommend that instream practices, including two-stage ditches, should be implemented in concert with landscape management practices, such as cover crops and precision fertilizer application, which reduce $\mathrm{N}$ export from fields to surface waters (Dinnes et al. 2002). As our data have shown, the two-stage ditch has the potential to increase $\mathrm{NO}_{3}{ }^{-}$removal rates in stream reaches via denitrification, but must be considered part of a suite of complementary surface water and landscape management practices, in which $\mathrm{N}$ removal is enhanced at multiple landscape locations.

\section{ACKNOWLEDGMENTS}

Many thanks to K. Wamsley and C. Watts for help with site selection, construction logistics, and field work. We greatly appreciate the efforts of T. Frauendorf, N. Griffiths, C. Turner, C. Walz, and M. Williams, who helped with field and laboratory work. We thank private land owners for access to the site. We also thank Peter Groffman and an anonymous reviewer for providing helpful comments, which greatly improved this manuscript. This project was funded by grants from the Indiana Department of Environmental Management and The Nature Conservancy. S. S. Roley and M. L. Stephen were funded by the Arthur J. Schmitt Foundation and GLOBES, an NSF IGERT Grant number 0504495. J. J. Beaulieu and L. T. Johnson were supported by the Center for Aquatic Conservation at the University of Notre Dame.

\section{Literature Cited}

Alexander, R. B., R. A. Smith, and G. E. Schwarz. 2000. Effect of stream channel size on the delivery of nitrogen to the Gulf of Mexico. Nature 403:758-761.

APHA [American Public Health Association]. 1995. Standard methods for the examination of water and wastewater. 19th edition. APHA, Washington, D.C., USA.
Arango, C. P., and J. L. Tank. 2008. Land use influences the spatiotemporal controls on nitrification and denitrification in headwater streams. Journal of the North American Benthological Society 27:90-107.

Arango, C. P., J. L. Tank, J. L. Schaller, T. V. Royer, M. J. Bernot, and M. B. David. 2007. Benthic organic carbon influences denitrification in streams with high nitrate concentration. Freshwater Biology 52:1210-1222.

Bernhardt, E. S., and G. E. Likens. 2002. Dissolved organic carbon enrichment alters nitrogen dynamics in a forest stream. Ecology 83:1689-1700.

Bernhardt, E. S., et al. 2005. Ecology: Synthesizing US river restoration efforts. Science 308:636-637.

Bernot, M. J., W. K. Dodds, W. S. Gardner, M. J. McCarthy, D. Sobolev, and J. L. Tank. 2003. Comparing denitrification estimates for a Texas estuary by using acetylene inhibition and membrane inlet mass spectrometry. Applied and Environmental Microbiology 69:5950-5956.

Böhlke, J. K., J. W. Harvey, and M. A. Voytek. 2004. Reachscale isotope tracer experiment to quantify denitrification and related processes in a nitrate-rich stream, midcontinent United States. Limnology and Oceanography 49:821-838.

Borin, M., and D. Tocchetto. 2007. Five year water and nitrogen balance for a constructed surface flow wetland treating agricultural drainage waters. Science of the Total Environment 380:38-47.

Brock, T. D. 1961. Chloramphenicol. Bacteriological Reviews 25:32-48.

Bruesewitz, D. A., J. L. Tank, and M. J. Bernot. 2008. Delineating the effects of zebra mussels (Dreissena polymorpha) on $\mathrm{N}$ transformation rates using laboratory mesocosms. Journal of the North American Benthological Society 27:236-251.

Bruesewitz, D. A., J. L. Tank, and S. K. Hamilton. 2009. Seasonal effects of zebra mussels on littoral nitrogen transformation rates in Gull Lake, Michigan, USA. Freshwater Biology 54:1427-1443.

Carpenter, S. R., N. F. Caraco, D. L. Correll, R. W. Howarth, A. N. Sharpley, and V. H. Smith. 1998. Nonpoint pollution of surface waters with phosphorus and nitrogen. Ecological Applications 8:559-568.

Christensen, P. B., L. P. Nielsen, J. Sorensen, and N. P. Revsbech. 1990. Denitrification in nitrate-rich streams: diurnal and seasonal variation related to benthic oxygen metabolism. Limnology and Oceanography 35:640-651.

Craig, L. S., et al. 2008. Stream restoration strategies for reducing river nitrogen loads. Frontiers in Ecology and the Environment 6:529-538.

David, M. B., L. G. Wall, T. V. Royer, and J. L. Tank. 2006. Denitrification and the nitrogen budget of a reservoir in an agricultural landscape. Ecological Applications 16:21772190 .

Dinnes, D. L., D. L. Karlen, D. B. Jaynes, T. C. Kaspar, J. L. Hatfield, T. S. Colvin, and C. A. Cambardella. 2002. Nitrogen management strategies to reduce nitrate leaching in tile-drained midwestern soils. Agronomy Journal 94:153171.

Ducros, C. M. J., and C. B. Joyce. 2003. Field-based evaluation tool for riparian buffer zones in agricultural catchments. Environmental Management 32:252-267.

Duff, J. H., F. J. Triska, and R. S. Oremland. 1984. Dentrification associated with stream periphyton: chamber estimates from undisrupted communities. Journal of Environmental Quality 13:514-518.

Fan, A. M., and V. E. Steinberg. 1996. Health implications of nitrate and nitrite in drinking water: An update on methemoglobinemia occurrence and reproductive and developmental toxicity. Regulatory Toxicology and Pharmacology 23:35-43.

Fennessy, M. S., and J. K. Cronk. 1997. The effectiveness and restoration potential of riparian ecotones for the manage- 
ment of nonpoint source pollution, particularly nitrate. Critical Reviews in Environmental Science and Technology 27:285-317.

Galloway, J. N., J. D. Aber, J. W. Erisman, S. P. Seitzinger, R. W. Howarth, E. B. Cowling, and B. J. Cosby. 2003. The nitrogen cascade. BioScience 53:341-356.

García-Ruiz, R., S. N. Pattinson, and B. A. Whitton. 1998 Denitrification in river sediments: relationship between process rate and properties of water and sediment. Freshwater Biology 39:467-476.

Gift, D. M., P. M. Groffman, S. S. Kaushal, and P. M. Mayer. 2010. Denitrification potential, root biomass, and organic matter in degraded and restored urban riparian zones. Restoration Ecology 18:113-120.

Gordon, N. D., T. A. McMahon, and B. L. Finlayson. 1992. Stream hydrology: an introduction for ecologists. Wiley, Chichester, UK.

Gore, J. A. 2006. Discharge measurements and streamflow analysis. Pages 51-71 in F. R. Hauer and G. L. Lamberti, editors. Methods in stream ecology. Academic Press, San Diego, California, USA.

Groffman, P. M., and M. K. Crawford. 2003. Denitrification potential in urban riparian zones. Journal of Environmental Quality 32:1144-1149.

Groffman, P. M., E. A. Holland, D. D. Myrold, G. P. Robertson, and X. Zou. 1999. Denitrification. Pages 272-288 in G. P. Robertson, D. C. Coleman, C. S. Bledsoe, and P. Sollins, editors. Standard soil methods for long-term ecological research. Oxford University Press, New York, New York, USA.

Hedin, L. O., J. C. von Fischer, N. E. Ostrom, B. P. Kennedy, M. G. Brown, and G. P. Robertson. 1998. Thermodynamic constraints on nitrogen transformations and other biogeochemical processes at soil-stream interfaces. Ecology 79:684703.

Helsel, D. R. 2005. Non-detects and data analysis: Statistics for censored environmental data. John Wiley and Sons, Hoboken, New Jersey, USA.

Hoffmann, C. C., M. L. Pedersen, B. Kronvang, and L. Ovig. 1998. Restoration of the rivers Brede, Cole and Skerne: a joint Danish and British EU-LIFE demonstration project, IV: Implications for nitrate and iron transformation. Aquatic Conservation-Marine and Freshwater Ecosystems 8:223-240.

Iman, R. L., and W. J. Conover. 1979. The use of the rank transform in regression. Technometrics 21:499-509.

Inwood, S. E., J. L. Tank, and M. J. Bernot. 2005. Patterns of denitrification associated with land use in 9 midwestern headwater streams. Journal of the North American Benthological Society 24:227-245.

Inwood, S. E., J. L. Tank, and M. J. Bernot. 2007. Factors controlling sediment denitrification in midwestern streams of varying land use. Microbial Ecology 53:247-258.

Johnson, L. B., C. Richards, G. E. Host, and J. W. Arthur. 1997. Landscape influences on water chemistry in Midwestern stream ecosystems. Freshwater Biology 37:193-208.

Kallio, R. M. 2010a. Evaluation of channel evolution and extreme event routing for two-stage ditches in a tri-state region of U.S.A. Thesis. Ohio State University, Columbus, Ohio, USA.

Kallio, S. E. 2010b. Determining the bankfull discharge exceedance potential of agricultural ditches in Ohio. Thesis. Ohio State University, Columbus, Ohio, USA.

Kaushal, S. S., P. M. Groffman, P. M. Mayer, E. Striz, and A. J. Gold. 2008. Effects of stream restoration on denitrification in an urbanizing watershed. Ecological Applications 18:789-804.

Kemp, M. J., and W. K. Dodds. 2002. Comparisons of nitrification and denitrification in prairie and agriculturally influenced streams. Ecological Applications 12:998-1009.

Knowles, R. 1982. Denitrification. Microbiological Reviews 46:43-70.
Kovacic, D. A., M. B. David, L. E. Gentry, K. M. Starks, and R. A. Cooke. 2000. Effectiveness of constructed wetlands in reducing nitrogen and phosphorus export from agricultural tile drainage. Journal of Environmental Quality 29:12621274.

Kovacic, D. A., R. M. Twait, M. P. Wallace, and J. M. Bowling. 2006. Use of created wetlands to improve water quality in the Midwest-Lake Bloomington case study. Ecological Engineering 28:258-270.

Landwehr, K., and B. L. Rhoads. 2003. Depositional response of a headwater stream to channelization, east central Illinois, USA. River Research and Applications 19:77-100.

Laursen, A. E., and S. P. Seitzinger. 2004. Diurnal patterns of denitrification, oxygen consumption and nitrous oxide production in rivers measured at the whole-reach scale. Freshwater Biology 49:1448-1458.

Mitsch, W. J., J. W. Day, J. W. Gilliam, P. M. Groffman, D. L. Hey, G. W. Randall, and N. M. Wang. 2001. Reducing nitrogen loading to the Gulf of Mexico from the Mississippi River Basin: strategies to counter a persistent ecological problem. BioScience 51:373-388.

Mitsch, W. J., J. W. Day, L. Zhang, and R. R. Lane. 2005. Nitrate-nitrogen retention in wetlands in the Mississippi River Basin. Ecological Engineering 24:267-278.

Mitsch, W. J., and J. G. Gosselink. 2000. Wetlands. Third edition. John Wiley and Sons, New York, New York, USA.

Mulholland, P. J., et al. 2008. Stream denitrification across biomes and its response to anthropogenic nitrate loading. Nature 452:202-246.

Mulholland, P. J., et al. 2009. Nitrate removal in stream ecosystems measured by $\mathrm{N}-15$ addition experiments: denitrification. Limnology and Oceanography 54:666-680.

Mulholland, P. J., H. M. Valett, J. R. Webster, S. A. Thomas, L. W. Cooper, S. K. Hamilton, and B. J. Peterson. 2004. Stream denitrification and total nitrate uptake rates measured using a field N-15 tracer addition approach. Limnology and Oceanography 49:809-820.

Naiman, R. J., H. Decamps, J. Pastor, and C. A. Johnston. 1988. The potential importance of boundaries to fluvial ecosystems. Journal of the North American Benthological Society 7:289-306.

Newbold, J. D., J. W. Elwood, R. V. O'Neill, and W. VanWinkle. 1981. Measuring nutrient spiralling in streams. Canadian Journal of Fisheries and Aquatic Sciences 38:860 863.

Nielsen, L. P., P. B. Christensen, N. P. Revsbech, and J. Sorensen. 1990. Denitrification and photosynthesis in stream sediment studied with microsensor and whole-core techniques. Limnology and Oceanography 35:1135-1144.

Orr, C. H., E. H. Stanley, K. A. Wilson, and J. C. Finlay. 2007. Effects of restoration and reflooding on soil denitrification in a leveed midwestern floodplain. Ecological Applications 17:2365-2376.

Osborne, L. L., and M. J. Wiley. 1988. Empirical relationships between land-use cover and stream water quality in an agricultural watershed. Journal of Environmental Management 26:9-27.

Palmer, M., J. D. Allan, J. Meyer, and E. S. Bernhardt. 2007. River restoration in the twenty-first century: data and experiential future efforts. Restoration Ecology 15:472-481.

Pattinson, S. N., R. García-Ruiz, and B. A. Whitton. 1998. Spatial and seasonal variation in denitrification in the SwaleOuse system, a river continuum. Science of the Total Environment 210:289-305.

Pfenning, K. S., and P. B. McMahon. 1996. Effect of nitrate, organic carbon, and temperature on potential denitrification rates in nitrate-rich riverbed sediments. Journal of Hydrology 187:283-295.

Piña-Ochoa, E., and M. Álvarez-Cobelas. 2006. Denitrification in aquatic environments: a cross-system analysis. Biogeochemistry $81: 111-130$. 
Pinay, G., L. Roques, and A. Fabre. 1993. Spatial and temporal patterns of denitrification in a riparian forest. Journal of Applied Ecology 30:581-591.

Poe, A. C., M. F. Piehler, S. P. Thompson, and H. W. Paerl. 2003. Denitrification in a constructed wetland receiving agricultural runoff. Wetlands 23:817-826.

Powell, G. E., A. D. Ward, D. E. Mecklenburg, J. Draper, and W. Word. 2007. Two-stage channel systems: Part 2, case studies. Journal of Soil and Water Conservation 62:286-296.

Powell, K. L., and V. Bouchard. 2010. Is denitrification enhanced by the development of natural fluvial morphology in agricultural headwater ditches? Journal of the North American Benthological Society 29:761-772.

Pribyl, A. L., J. H. McCutchan, W. M. Lewis, and J. F. Saunders. 2005. Whole-system estimation of denitrification in a plains river: a comparison of two methods. Biogeochemistry 73:439-455.

R Core Development Team. 2010. R version 2.11.1. R Foundation for Statistical Computing, Vienna, Austria.

Rabalais, N. N., R. E. Turner, and W. J. Wiseman. 2002. Gulf of Mexico hypoxia, aka "The dead zone." Annual Review of Ecology and Systematics 33:235-263.

Randall, G. W., D. R. Huggins, M. P. Russelle, D. J. Fuchs, W. W. Nelson, and J. L. Anderson. 1997. Nitrate losses through subsurface tile drainage in Conservation Reserve Program, alfalfa, and row crop systems. Journal of Environmental Quality 26:1240-1247.

Royer, T. V., M. B. David, and L. E. Gentry. 2006. Timing of riverine export of nitrate and phosphorus from agricultural watersheds in Illinois: implications for reducing nutrient loading to the Mississippi River. Environmental Science and Technology 40:4126-4131.

Royer, T. V., J. L. Tank, and M. B. David. 2004. Transport and fate of nitrate in headwater agricultural streams in Illinois. Journal of Environmental Quality 33:1296-1304.

Schaller, J. L., T. V. Royer, M. B. David, and J. L. Tank. 2004. Denitrification associated with plants and sediments in an agricultural stream. Journal of the North American Benthological Society 23:667-676.

Schilling, K. E., and P. Jacobson. 2009. Water uptake and nutrient concentrations under a floodplain oak savanna during a non-flood period, lower Cedar River, Iowa. Hydrological Processes 23:3006-3016.

Seitzinger, S., J. A. Harrison, J. K. Böhlke, A. F. Bouwman, R. Lowrance, B. Peterson, C. Tobias, and G. Van Drecht. 2006.
Denitrification across landscapes and waterscapes: A synthesis. Ecological Applications 16:2064-2090.

Sheibley, R. W., D. S. Ahearn, and R. A. Dahlgren. 2006. Nitrate loss from a restored floodplain in the lower Cosumnes River, California. Hydrobiologia 571:261-272.

Smith, L. K., J. J. Sartoris, J. S. Thullen, and D. C. Andersen. 2000. Investigation of denitrification rates in an ammoniadominated constructed wastewater-treatment wetland. Wetlands 20:684-696.

Smith, M. S., and J. M. Tiedje. 1979. Phases of denitrification following oxygen depletion in soil. Soil Biology and Biochemistry 11:261-267.

SSSA [Soil Science Society of America]. 1996. Methods of soil analysis. SSSA, Madison, Wisconsin, USA.

Stanley, E. H., and J. T. Maxted. 2008. Changes in the dissolved nitrogen pool across land cover gradients in Wisconsin streams. Ecological Applications 18:1579-1590.

Stewart-Oaten, A., W. W. Murdoch, and K. R. Parker. 1986. Environmental-impact assessment: "pseudoreplication" in time? Ecology 67:929-940.

SYSTAT Software. 2007. SYSTAT. Version 12. SYSTAT Software, Chicago, Illinois, USA

Tank, J. L., and W. K. Dodds. 2003. Nutrient limitation of epilithic and epixylic biofilms in ten North American streams. Freshwater Biology 48:1031-1049.

Triska, F. J., and R. S. Oremland. 1981. Denitrification associated with periphyton communities. Applied and Environmental Microbiology 42:745-748.

Van Der Lee, G. E. M., H. O. Venterink, and N. E. M. Asselman. 2004. Nutrient retention in floodplains of the Rhine distributaries in The Netherlands. River Research and Applications 20:315-325.

Vidon, P., L. E. Wagner, and E. Soyeux. 2008. Changes in the character of DOC in streams during storms in two Midwestern watersheds with contrasting land uses. Biogeochemistry 88:257-270.

Vitousek, P. M., J. D. Aber, R. W. Howarth, G. E. Likens, P. A. Matson, D. W. Schindler, W. H. Schlesinger, and D. G. Tilman. 1997. Human alteration of the global nitrogen cycle: sources and consequences. Ecological Applications 7:737750 .

Wall, L. G., J. L. Tank, T. V. Royer, and M. J. Bernot. 2005. Spatial and temporal variability in sediment denitrification within an agriculturally influenced reservoir. Biogeochemistry 76:85-111. 